\title{
Tardigrades from Larus dominicanus Lichtenstein, 1823 nests on the Argentine Islands (maritime Antarctic)
}

\author{
Lukasz Kaczmarek $^{1} \cdot$ Ivan Parnikoza $^{2} \cdot$ Magdalena Gawlak $^{3} \cdot$ Jan Esefeld $^{4}$. \\ Hans-Ulrich Peter ${ }^{4} \cdot$ Iryna Kozeretska $^{5} \cdot$ Milena Roszkowska $^{1}$
}

Received: 27 October 2016/Revised: 25 July 2017/ Accepted: 28 July 2017/Published online: 16 September 2017

(C) The Author(s) 2017. This article is an open access publication

\begin{abstract}
Tardigrada in Antarctic regions are poorly known. The aim of this study was to examine for tardigrades the nests material of the kelp gull (Larus dominicanus Lichtenstein, 1823 ) in maritime Antarctic and discuss the possible ways of migration and dispersion of tardigrades by birds. We also discuss the influence of bird's guano on the communities of microscopic invertebrates (mainly tardigrades). In the positive samples (mainly bryophytes and lichens) of seven Larus dominicanus nests, collected on Ardley Island (near Fildes Peninsula) and Argentine Islands, ca. 850 tardigrades and their eggs were found. In total, 13 taxa (including Ramajendas sp.) were identified, and four are new to science: Bryodelphax olszanowskii sp. nov., Diphascon puchalskii sp. nov., D. rudnickii sp. nov. and Hypsibius conwentzii sp. nov.. Bryodelphax olszanowskii sp. nov. differs from known
\end{abstract}

Milena Roszkowska

mil.roszkowska@gmail.com

Łukasz Kaczmarek

kaczmar@amu.edu.pl

Ivan Parnikoza

ivan.parnikoza@gmail.com

Magdalena Gawlak

mgieta.post@home.pl

Jan Esefeld

jan.esefeld@uni-jena.de

Hans-Ulrich Peter

hans-ulrich.peter@uni-jena.de

Iryna Kozeretska

iryna.kozeretska@gmail.com

1 Department of Animal Taxonomy and Ecology, Institute of Environmental Biology, Faculty of Biology, Adam

Mickiewicz University, Poznań, Umultowska 89,

61-614 Poznań, Poland
Bryodelphax species in the weglarskae group mainly by having a different ventral plate configuration. Belonging to the pingue group, D. puchalskii sp. nov. differs from other species by some quantitative characters and $D$. rudnickii sp. nov. by having the first and second macroplacoids situated very close to each other. Hypsibius conwentzii sp. nov. differs from other species of the genus Hypsibius, with two macroplacoids and septulum, by some morphological and morphometric characters. Summarizing, Antarctic tardigrades are a very diverse group, and birds can be responsible for translocation of small invertebrates (including tardigrades) inside of various parts of plants and lichens. They also deposit large amounts of guano, which provides a lot of nutrients for poor tundra ecosystems and support small invertebrate communities.

2 Institute of Molecular Biology and Genetics of National, Academy of Science of Ukraine, Akademica Zabolotnogo str., 150, Kyiv 03143, Ukraine

3 The Institute of Plant Protection-National Research Institute, Węgorka 20, 60-318 Poznań, Poland

4 Institute of Ecology and Evolution, University Jena, Dornburger Str. 159, 07743 Jena, Germany

5 Taras Shevchenko National University of Kyiv, Volodymyrska Str., 64, Kyiv 01601, Ukraine 
Keywords Bryodelphax - Diphascon - Dispersion · Fauna . Hypsibius · Kelp gull nests · New species · Tardigrada

\section{Introduction}

Antarctica is one of the most extremely unsuited habitats on the planet, with very low temperatures and the lack of liquid water. It covers ca. 14 million square kilometres and only ca. $0.3 \%$ of this area is ice-free. Since ca. 28 million years ago, it has been isolated from other continents by the Southern Ocean. The continent is divided into three units: East Antarctica, West Antarctica, and the Antarctic Peninsula (Kimble 2004). All areas of the western coast as far south as southern Alexander Island (around $72^{\circ} \mathrm{S}$ ), the archipelagos of the South Shetland, South Orkney, and South Sandwich Islands and the isolated Bouvet and Peter I Islands are called the maritime Antarctic (Riffenburh 2007).

The maritime Antarctic is a region with the richest biodiversity in this part of the world. Here is the most diverse vegetation (algae, lichens, bryophytes: liverworts and mosses, and two species of vascular plants) in the Antarctic. Because of variable biological and physicochemical conditions, different regions of the maritime Antarctic may show varied levels of biodiversity (Lindsay 1971; Smith and Corner 1973). These regions are also characterized by the highest rates of regional climate warming recorded on the planet, which can result in fast changes in local biodiversity (Turner et al. 2005; Convey et al. 2009). However, most regions of Antarctica are not sufficiently investigated, especially in terms of microinvertebrates. Our knowledge of these organisms is patchy and fragmented, because most studies are focused on very accessible regions around research stations. Microfauna are associated with habitats which are rich in organic material, i.e. algae, mosses and lichens or in the vicinity of bird colonies (Velasco-Castrillón et al. 2014). Among all Antarctic invertebrates most of them are endemic, some of them have a continental distribution, others are restricted only to maritime and only few can be characterized as panAntarctic species (e.g. Pugh and Convey 2008). Microfaunal taxa like rotifers, nematodes, or tardigrades have a crucial role in nutrient recycling and their assemblages are extremely important for Antarctic limnoterrestrial ecosystems. However, as of now only ca. 30 bdelloid rotifers, ca. 70 monogonont rotifers, ca.70 nematodes and 62 tardigrades species are known from the entire Antarctic region (e.g. Velasco-Castrillón et al. 2014; Vecchi et al. 2016), which allows us to suppose that most of the microinvertebrates in this region are still unknown.

The Phylum Tardigrada currently consists of ca. 1200 taxa (Guidetti and Bertolani 2005; Degma and Guidetti
2007; Degma et al. 2009-2017; Vicente and Bertolani 2013) that inhabit terrestrial and aquatic (both freshwater and marine) environments throughout the world (Nelson et al. 2015). Studies on Antarctic tardigrades started in the beginning of the twentieth century and have progressed rather slowly up to now. Currently, most of the 62 Antarctic tardigrades have been reported from continental Antarctic and the Antarctic Peninsula [for review see Convey and McInnes (2005) and later publications: Binda et al. (2005), McInnes (2010), Pilato et al. (2012a), Guidetti et al. (2014), Kaczmarek et al. (2014a), Tsujimoto et al. (2014), Velasco-Castrillón et al. (2014), Vecchi et al. (2016)], and few from other regions. Moreover, little to nothing is known about possible spreading routes of tardigrades in maritime Antarctic. Typical microhabitats for limnoterrestrial tardigrades are mosses and lichens (Nelson et al. 2015), which are also used for padding nests of many Antarctic birds. In preliminary research, many unidentified tardigrades were found in samples collected from bird nests (I. Dykyy personal communication, 2006). The aim of this study was to examine for tardigrades the nests material of the kelp gull (Larus dominicanus Lichtenstein, 1823) from two regions of maritime Antarctic (King George Island with neighbouring Ardley Island and Argentine Islands).

In total, 12 nests from King George Island (including Ardley Island) and Argentine Islands were studied (but only in seven water bears were found) and 13 tardigrade taxa (12 identified to the species level) were discovered. Four species are new to science and two are new records for the Antarctic Peninsula region.

\section{Materials and methods}

\section{Sample processing}

Samples of nest material from six nests of $L$. dominicanus were collected by hand on the Fildes Peninsula and nearby of Ardley Island and King George Island during the work of German Polar Ecology Group in February in 2015. The next six nests from the Argentine Islands were collected during the 19th Ukrainian Antarctic Expedition in February-April in 2014) (Fig. 1). Samples for analysis (ca. $15 \mathrm{~cm}^{2}$ ) were collected after nesting period during field investigation of the islands and contained vegetation nest materials: Deschampsia antarctica E. Desv., cushions of Sanionia sp., other bryophytes and dry lichens, mainly Usnea antarctica Du Rietz (in total 15-30 g). All samples were packed in paper envelopes, dried in temperature $25{ }^{\circ} \mathrm{C}$ and delivered to the laboratory at the Faculty of Biology, Adam Mickiewicz University, Poznań, Poland. Tardigrades were extracted from the samples $\left(\mathrm{ca} .5 \mathrm{~cm}^{2}\right.$ of 


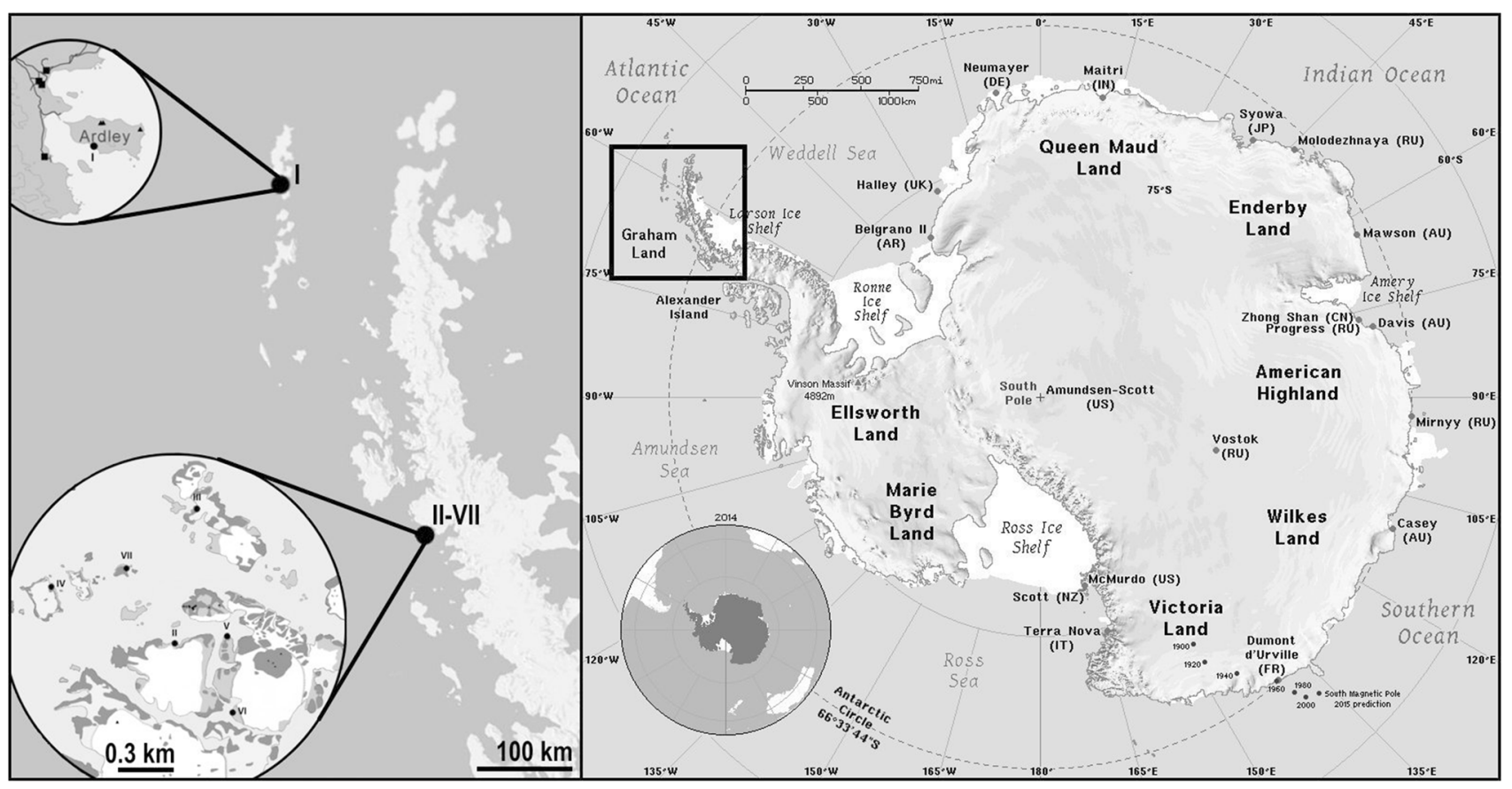

Fig. 1 Map of positive sampling sites

each sample was examined) and studied following the protocol by Stec et al. (2015). All tardigrade specimens were mounted on microscope slides in Hoyer's medium.

\section{Microscopy and imaging}

Specimens for light microscopy were mounted on microscope slides in a small drop of Hoyer's medium, prepared according to Ramazzotti and Maucci (1983) as in the English translation by Beasley (1995), and secured with a cover slip. The slides were then placed in an incubator and dried for two days at ca. $60{ }^{\circ} \mathrm{C}$. Dried slides were sealed with a transparent nail polish and examined under an Olympus BX41 phasecontrast light microscope (PCM) associated with a $A R T$ CAM-300Mi digital camera (Olympus Corporation, Shinjuku-ku, Japan). A total of 10 specimens of Bryodelphax olszanowskii sp. nov. were prepared for scanning electron microscopy (SEM) imaging according to Stec et al. (2015). These animals were examined under high vacuum in a Hitachi S3000N Scanning Electron Microscope.

All figures were assembled in Corel Photo-Paint 9. For deep structures that could not be fully focused in a single photograph, a series of 2-10 images were taken every ca. $0.5 \mu \mathrm{m}$ and then assembled into a single deep-focus image manually in Corel Photo-Paint 9.

\section{Morphometrics and morphological nomenclature}

All measurements are given in micrometres $(\mu \mathrm{m})$. Structures were measured only if their orientation was suitable.
Body length was measured from the anterior extremity to the end of the body, excluding the hind legs. The types of bucco-pharyngeal apparatuses and claws were classified according to Pilato and Binda (2010). Buccal tube length, the level of the stylet support insertion point, and placoid lengths were measured according to Pilato (1981) and Pilato and Binda (1999). Buccal tube width was measured as the external and internal diameter at the level of the stylet support insertion point. The macroplacoid length sequence was determined according to Kaczmarek et al. (2014b). Lengths of the claw branches for Diphascon were measured according to Pilato and Binda (1999), for Hypsibius according to Beasley et al. (2008) and for Bryodelphax from the base of the claw to the top of the branch. The terminology used to describe the genus Bryodelphax follows Kristensen (1987). The pt/ptd ratio is the ratio of the length of a given structure to the length of the buccal tube expressed as a percentage (Pilato 1981; Pilato and Binda 1997/1998). The $s c$ ratio is the ratio of the length of a given structure to the length of the scapular plate (e.g. Fontoura and Morais 2011). The configuration of ventral plates in the genus Bryodelphax is described according to Kaczmarek et al. (2012).

Morphometric data were handled using the "Parachela" ver. 1.1 and "Echiniscoidea" ver. 1.1 templates available from the Tardigrada Register (Michalczyk and Kaczmarek 2013). Tardigrade taxonomy follows Bertolani et al. (2014).

Raw data underlying the description of B. olszanowskii sp. nov., D. puchalskii sp. nov., D. rudnickii sp. nov. and $H$. 
conwentzii sp. nov. are deposited in the Tardigrada Register (Michalczyk and Kaczmarek 2013) under http:// www.tardigrada.net/register/0039.htm., http://www.tardi grada.net/register/0040.htm., http://www.tardigrada.net/reg ister/0041.htm., and http://www.tardigrada.net/register/ 0042.htm., respectively.

\section{Comparative material}

The species were identified based on the keys in Ramazzotti and Maucci (1983) [with English translation by Beasley (1995)] and Fontoura and Pilato (2007), and more recent papers and original descriptions: Doyère (1840), Pilato (1972, 1974), Dastych (1984), Binda and Pilato (1992), Bertolani et al. (1996), Tumanov (1997), Pilato and Binda (1997, 1997b), Pilato and Binda (1999), Dastych (2002), Pilato et al. (2004, 2006, 2012b), Binda et al. (2005), Miller et al. (2005), Kristensen et al. (2010), Kaczmarek et al. (2012), and Gąsiorek et al. (2017). Morphometric data for H. dujardini (Doyère, 1840) are according to Pilato et al. (2012b).

\section{Localities of positive samples (Fig. 1)}

I. $62^{\circ} 12.915 ’ \mathrm{~S}, 58^{\circ} 56.301^{\prime} \mathrm{W}, 5 \mathrm{~m}$ asl, Ardley Island, near King George Island, L. dominicanus nest (bryophytes-40\%, lichens-25\% of the entire nest material), date: 02.2015, coll. J. Esefeld, (139 tardigrades, 24 exuvia, 18 eggs).

II. $65^{\circ} 14.859^{\prime} \mathrm{S}, \quad 64^{\circ} 15.578^{\prime} \mathrm{W}, 6 \mathrm{~m}$ asl, Argentine Islands, Winter Island, L. dominicanus nest (bryophytes-82\%, Deschampsia antarctica-15\%, lichens $-1 \%$ of the entire nest material), date: 02.2014, coll. I. Parnikoza, (1 tardigrade).

III. $65^{\circ} 14.442^{\prime} \mathrm{S}, 64^{\circ} 15.286^{\prime} \mathrm{W}, 13 \mathrm{~m}$ asl, Argentine Islands, Grotto Island, L. dominicanus nest (bryophytes-61\%, lichens-20\%, D. antarctica-15\% of the entire nest material), date: 02.2014, coll. I. Parnikoza, (111 tardigrades, 9 exuvia).

IV. $65^{\circ} 14.554^{\prime} \mathrm{S}, 64^{\circ} 16.431^{\prime} \mathrm{W}, 12 \mathrm{~m}$ asl, Argentine Islands, Central Island of Three Little Pigs, $L$. dominicanus nest (bryophytes-85\%, lichens-1\% of the entire nest material), date: 02.2014, coll. I. Parnikoza, (275 tardigrades, 74 exuvia, 111 eggs).

V. $65^{\circ} 14.842^{\prime} \mathrm{S}, 64^{\circ} 15.179^{\prime} \mathrm{W}, 4 \mathrm{~m}$ asl, Argentine Islands, Galindez Island, Stella Point, L. dominicanus nest (bryophytes-61\%, D. antarctica-35\%, lichens $-1 \%$ of the entire nest material), date: 02.2014, coll. I. Parnikoza, (10 tardigrades, 2 exuvia).

VI. $65^{\circ} 15.079^{\prime} \mathrm{S}, \quad 64^{\circ} 15.138^{\prime} \mathrm{W}, 4 \mathrm{~m}$ asl, Argentine Islands, Galindez Island, Sterna Point, L. dominicanus nest (bryophytes-63\%, D. antarctica-30\% of the entire nest material), date: 02.2014, coll. I. Parnikoza, (53 tardigrades, 6 eggs).

VII. $65^{\circ} 14.589^{\prime} \mathrm{S}, 64^{\circ} 15.864^{\prime} \mathrm{W}, 10 \mathrm{~m}$ asl, Argentine Islands, Batton Rock near Galindez Island, $L$. dominicanus nest (bryophytes-90\%, lichens-2\%, D. antarctica- $1 \%$ of the entire nest material), date: 02.2014, coll. I. Parnikoza, (9 tardigrades, 1 exuvia, 5 eggs).

\section{Results}

Among 12 samples, seven were positive and contained 598 tardigrades and 140 freely laid eggs, which were attributed to 13 taxa (including four species new for science). The 110 specimens (exuvia) were not identified due to the lack of buccal apparatuses which are crucial for correct identification.

\section{Taxonomic account}

Phylum: Tardigrada Doyère, 1840

Class: Heterotardigrada Marcus, 1927

Family: ECHINISCIDAE Thulin, 1928

Genus: Bryodelphax Thulin, 1928

\section{Bryodelphax olszanowskii sp. nov}

Material examined: type material: 46 animals (holotype and 45 paratypes) mounted on microscope slides in Hoyer's medium and 10 animals prepared for SEM.

\section{Description of the new species}

\section{Animals (measurements and statistics in Table 1)}

Body (Fig. 2a-c) transparent to slightly white/pale yellow, eyes absent or not visible after the preparation. The mouth surrounded by 10 papullae which are visible only in SEM (Fig. 3a). Apart from the head appendages (internal and external cirri and drop-shaped cephalic papillae (secondary clava)), only lateral cirrus $A$ present (with clava near the base (primary clava).

Dorsal plates covered with fine, but distinct dark dots that appear as granulation under PCM, but are in fact cuticular pillars within the cuticle (Michalczyk and Kaczmarek 2006, 2007). "Granulation" distinctly larger on the scapular (Fig. 3b) and the terminal plates. In addition to the "granulation", slightly larger and irregularly distributed "pores" (depressions) are visible mainly on the margins of all dorsal plates (Fig. 2a). Scapular plate facetted with a median longitudinal fold and a few smaller transverse folds 
Table 1 Measurements [in $\mu \mathrm{m}$ ] and $s c$ values of selected morphological structures of Bryodelphax olszanowskii sp. nov. mounted in Hoyer's medium

\begin{tabular}{|c|c|c|c|c|c|c|c|c|c|c|c|c|c|}
\hline \multirow[t]{2}{*}{ Character } & \multirow[t]{2}{*}{$N$} & \multicolumn{6}{|c|}{ Range } & \multicolumn{2}{|c|}{ Mean } & \multicolumn{2}{|l|}{ SD } & \multicolumn{2}{|c|}{ Holotype } \\
\hline & & $\mu \mathrm{m}$ & & & $s c$ & & & $\mu \mathrm{m}$ & $s c$ & $\mu \mathrm{m}$ & $s c$ & $\mu \mathrm{m}$ & $s c$ \\
\hline Body length & 30 & 111 & - & 156 & & - & & 138 & - & 11 & - & 149 & - \\
\hline Scapular plate length & 30 & 17.6 & - & 21.6 & & - & & 19.4 & - & 1.0 & - & 20.4 & - \\
\hline \multicolumn{14}{|l|}{ Head appendages lengths } \\
\hline Cirrus internus & 28 & 6.3 & - & 7.8 & 29.6 & - & 39.6 & 7.0 & 36.2 & 0.4 & 2.1 & 7.8 & 38.2 \\
\hline Cephalic papilla & 27 & 3.2 & - & 4.9 & 17.8 & - & 23.8 & 4.0 & 20.8 & 0.4 & 1.9 & 3.7 & 18.1 \\
\hline Cirrus externus & 28 & 9.5 & - & 14.0 & 54.0 & - & 68.6 & 11.6 & 60.1 & 0.9 & 4.3 & 14.0 & 68.6 \\
\hline Clava & 24 & 3.0 & - & 4.3 & 15.7 & - & 21.6 & 3.6 & 18.5 & 0.4 & 1.6 & 4.2 & 20.6 \\
\hline Cirrus $A$ & 28 & 24.9 & - & 36.6 & 123.3 & - & 189.3 & 31.2 & 161.0 & 3.0 & 16.0 & 32.8 & 160.8 \\
\hline $\begin{array}{l}\text { Cirrus } A / \text { Body length } \\
\text { ratio }\end{array}$ & 28 & $19 \%$ & - & $27 \%$ & & - & & $23 \%$ & - & $2 \%$ & - & $22 \%$ & - \\
\hline Cirrus intlext length ratio & 28 & $52 \%$ & - & $68 \%$ & & - & & $60 \%$ & - & $5 \%$ & - & $56 \%$ & - \\
\hline \multicolumn{14}{|l|}{ Claw 1 lengths } \\
\hline Branch & 25 & 5.9 & - & 7.1 & 29.2 & - & 36.3 & 6.4 & 33.1 & 0.3 & 1.8 & 6.7 & 32.8 \\
\hline Spur & 23 & 1.3 & - & 2.0 & 7.0 & - & 10.7 & 1.7 & 8.7 & 0.2 & 1.1 & 1.7 & 8.3 \\
\hline Spur/branch length ratio & 23 & $20 \%$ & - & $32 \%$ & & - & & $26 \%$ & - & $3 \%$ & - & 0 & - \\
\hline \multicolumn{14}{|l|}{ Claw 2 lengths } \\
\hline Branch & 25 & 5.7 & - & 7.0 & 28.7 & - & 35.8 & 6.3 & 32.2 & 0.4 & 1.8 & 6.2 & 30.4 \\
\hline Spur & 21 & 1.2 & - & 1.9 & 6.0 & - & 10.0 & 1.6 & 8.1 & 0.2 & 1.1 & 1.8 & 8.8 \\
\hline Spur/branch length ratio & 21 & $21 \%$ & - & $30 \%$ & & - & & $25 \%$ & - & $3 \%$ & - & 0 & - \\
\hline \multicolumn{14}{|l|}{ Claw 3 lengths } \\
\hline Branch & 26 & 5.7 & - & 7.0 & 27.3 & - & 36.8 & 6.3 & 32.4 & 0.4 & 2.0 & 6.2 & 30.4 \\
\hline Spur & 20 & 1.2 & - & 1.9 & 6.0 & - & 10.2 & 1.6 & 8.3 & 0.2 & 1.1 & 1.8 & 8.8 \\
\hline Spur/branch length ratio & 20 & $19 \%$ & - & $31 \%$ & & - & & $26 \%$ & - & $3 \%$ & - & 0 & - \\
\hline \multicolumn{14}{|l|}{ Claw 4 lengths } \\
\hline Branch & 25 & 6.0 & - & 7.6 & 32.3 & - & 39.8 & 6.9 & 35.6 & 0.4 & 2.1 & 6.7 & 32.8 \\
\hline Spur & 16 & 1.3 & - & 2.0 & 6.8 & - & 10.5 & 1.7 & 8.7 & 0.3 & 1.3 & $?$ & $?$ \\
\hline Spur/branch length ratio & 16 & $21 \%$ & - & $29 \%$ & & - & & $24 \%$ & - & $3 \%$ & - & $?$ & - \\
\hline
\end{tabular}

$N$ number of specimens/structures measured, range refers to the smallest and the largest structure among all measured specimens, $S D$ standard deviation, ? trait oriented unsuitably for measurement, $s c$ ratio of the length of a given structure to the length of the scapular plate

(Figs. 2c, 3c). Paired plates divided into two unequal anterior and posterior parts by a transverse stripe without "granulation" (Fig. 3d). Median plates 1 and 2 divided, and median plate 3 undivided. Twelve supplementary plates poorly visible near median plates $1-3$ (Fig. 2a, arrowheads). The terminal plate facetted with two longitudinal folds (Fig. 3e).

Ventral plates oval and arranged in eight rows: 2 plates in row I (subcephalic), 1 plate in row II (between legs I), 1 plate in row III (between legs I and II), 2 plates in row IV (between legs I and II), 2 plates in row V (between legs II and III), 2 plates in row VI (between legs II and III), 2 plates in row VII (between legs III and IV) and 2 plates in row VIII (in line with the gonophore); i.e. the ventral plate configuration VIII:2-1-1-2-2-2-2-2 (Fig. 4a-c). Moreover an oval plate is present on the ventro-lateral side, close to the head plate (Fig. 4d). Entire ventral side covered with fine "granulation", visible only in PCM, which is more visible on plates (Fig. 5a-b). Another type of fine, irregular granulation is visible only in SEM (Fig. 5c). In addition, large dark granules (probably of epicuticular elevations) are also present on ventral plates (Fig. $5 \mathrm{a}-\mathrm{c}$ ).

Spines on legs I absent, papillas on legs IV present (Fig. 6a-b). Dentate collar on legs IV poorly developed (visible well only in SEM) and with variable number of teeth (Fig. 6b-c). External claws of all legs smooth, internal with spurs directed downwards (Fig. 6b, d-f).

Eggs unknown.

Remarks. In some specimens, ventral plates are indistinct (Fig. 5f); thus an examination of at least several specimens is strongly recommended to ensure correct identification. Moreover, in one specimen, some dark 

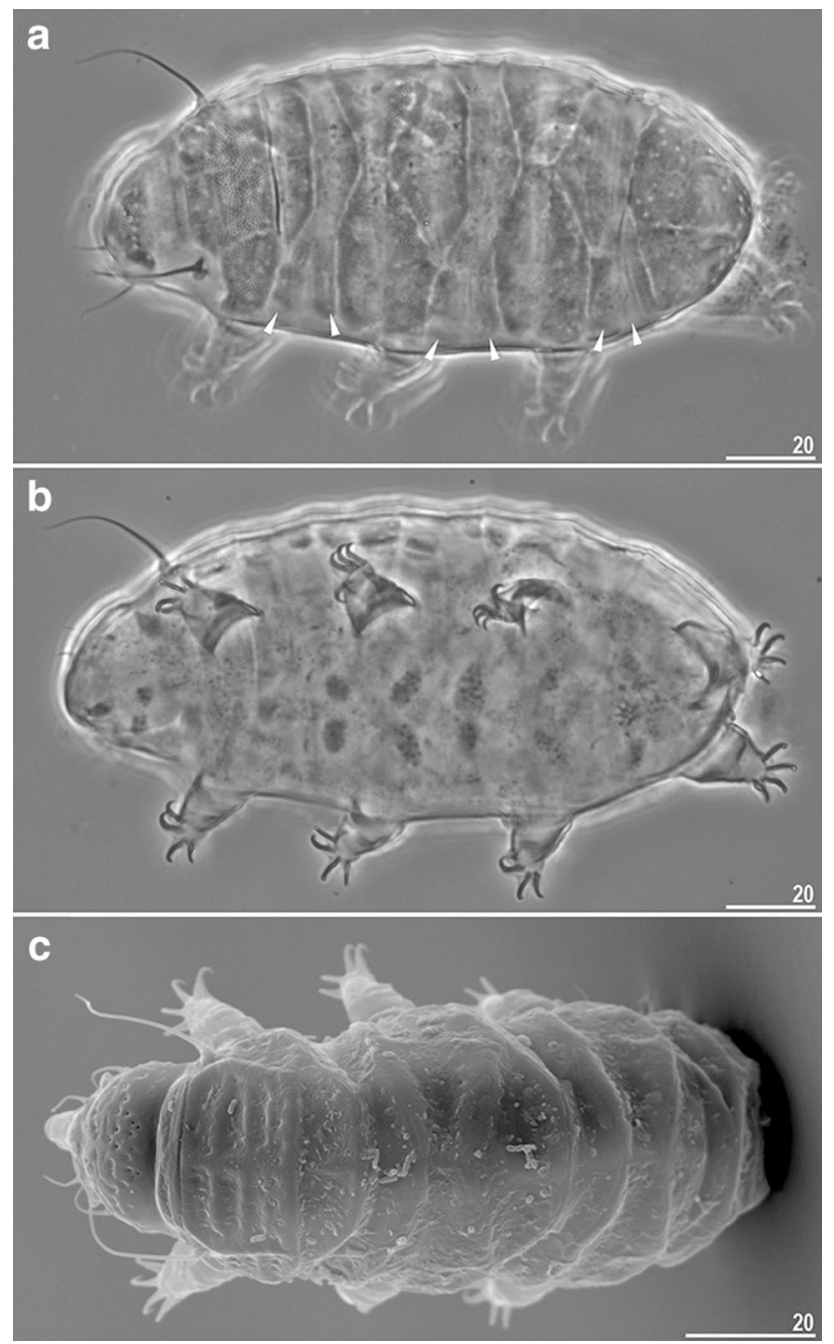

Fig. 2 a-c Bryodelphax olszanowskii sp. nov.: habitus: a dorsal projection, arrowheads indicate supplementary plates near median plates (holotype, PCM); b ventral projection (holotype, PCM); c dorsal projection (paratype, SEM) ( $P C M$ phase-contrast light microscope, SEM scanning electron microscopy)

granules simulating an additional ventral plate in row III were observed (Fig. 5e). The papillas on legs IV are hardly visible and only in lateral orientation of the specimen, which is why this character is not used in the differential diagnosis.

Etymology. We dedicate this species to a distinguished Polish acarologist, Professor Ziemowit Olszanowski, discoverer of many new species of Oribatida mites.

Type locality. III. $65^{\circ} 14.442^{\prime} \mathrm{S}, 64^{\circ} 15.286^{\prime} \mathrm{W}, 13 \mathrm{~m}$ asl, Argentine Islands, Grotto Island, L. dominicanus nest (bryophytes-61\%, lichens-20\%, D. antarctica-15\% of the entire nest material), date: 02.2014 , coll. Ivan Parnikoza.

Type depositories. Holotype: slide AT53/16 (with four paratypes) and 27 paratypes (slides: AT53/*, where the asterisk can be substituted by any of the following numbers: $3,8,10,11,14)$ are deposited at the Department of Animal Taxonomy and Ecology, Institute of Environmental Biology, Adam Mickiewicz University, Poznań, 10 paratypes (slide AT53/12) are deposited at the Zoological Museum, The Natural History Museum of Denmark, the University of Copenhagen, Universitetsparken 15, DK2100 Copenhagen $\varnothing$, Denmark and four paratypes (slide AT53/15) are deposited at collection of Binda and Pilato, the Museum of the Department of Animal Biology 'Marcello La Greca', the University of Catania, Italy.

\section{Differential diagnosis}

Bryodelphax olszanowskii sp. nov. has ventral plates and thus belongs to the weglarskae group (Kristensen et al. 2010); we therefore only compared it to other species of this group, using the ventral plates and other characters. The new species differs from

1. B. aaseae Kristensen et al., 2010 by a different ventral plate configuration (VIII:2-1-1-2-2-2-2-2 in the new species vs. X:2-1-4-4-2-4-2-1-2-1 in B. aaseae), the presence of large dark "granules/dots" on ventral plates and larger spurs on claws (1.2-2.0 in the new species vs. $0.8-1.1$ in B. aaseae).

2. B. iohannis Bertolani et al., 1995 by a different ventral plate configuration (VIII:2-1-1-2-2-2-2-2 in the new species vs. X:2-1-1-5-2-4-2-2-2-1 in B. iohannis) and the presence of large dark "granules/dots" on ventral plates.

3. B. maculatus Gąsiorek et al., 2017 by a different ventral plate configuration (VIII:2-1-1-2-2-2-2-2 in the new species vs. III:2-2-1 in B. maculatus).

4. B. parvuspolaris Kaczmarek et al., 2012 by a different ventral plate configuration (VIII:2-1-1-2-2-2-2-2 in the new species vs. VIII:1-1-2-2-2-2-2-1 in B. parvuspolaris), the presence of large dark "granules/dots" on ventral plates and larger $s c$ of spurs on claws (6.0-10.7 in the new species vs. 3.5-4.9 in B. parvuspolaris).

5. B. sinensis Pilato, 1974 by a different ventral plate configuration (VIII:2-1-1-2-2-2-2-2 in the new species vs. VII:2-2-2-2-2-2-1 in B. sinensis) and the presence of large dark "granules/dots" on ventral plates.

6. B. weglarskae Pilato, 1972 by a different ventral plate configuration (VIII:2-1-1-2-2-2-2-2 in the new species vs. IX:2-1-5-2-4-2-2-2-1 in B. weglarskae) and by appendages (cirrus internus, externus and cirri $A$ ) that are not bifurcated.

Genus: Echiniscus C.A.S. Schultze, 1840 
Fig. 3 a-e Bryodelphax olszanowskii sp. nov. (paratypes): a papullae around mouth opening (SEM); bc scapular plate (PCM and SEM respectively); d divided paired plates with a transverse stripe without "granulation" (PCM); e facetted terminal plate (SEM) (PCM phase-contrast light microscope, SEM scanning electron microscopy)
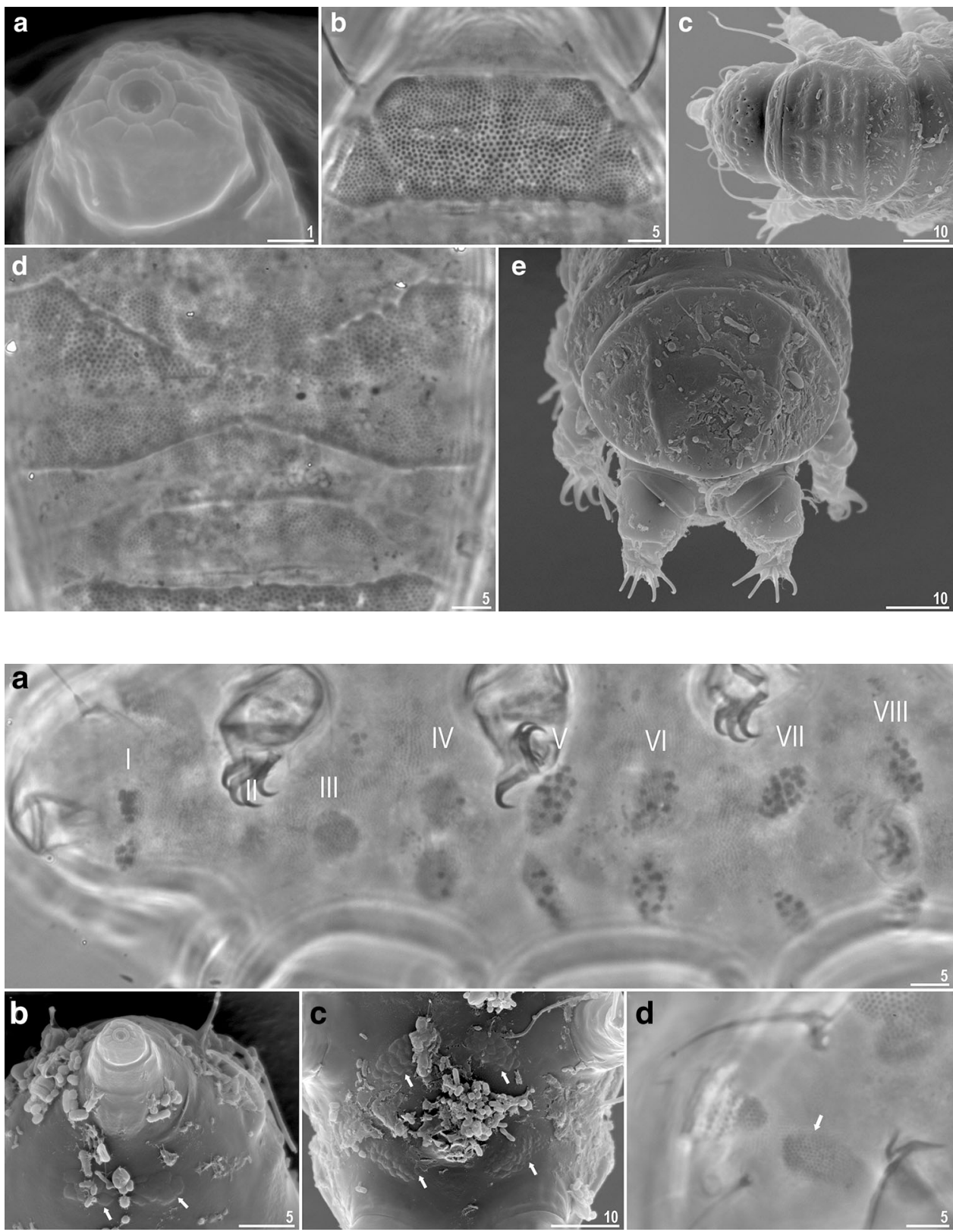

Fig. 4 a-d Bryodelphax olszanowskii sp. nov. (paratypes): a ventral plates arranged in eight rows, roman numbers indicate next rows of plates (PCM); b mouth opening and two subcephalic plates, arrows (SEM); c two plates in row VII and VIII, arrows (SEM); d oval plate on ventrolateral side close to the head plate, arrow (PCM) (PCM phase-contrast light microscope, SEM scanning electron microscopy)

\section{Echiniscus jenningsi Dastych, 1984}

Localities and number of specimens: I (13 animals) and VI (1).

Remarks: In the Antarctic region species known from Graham Land, Signy Island and the King George Island (Dastych 1984, Convey and McInnes 2005, Kaczmarek et al. 2014a).

\section{Echiniscus merokensis merokensis Richters, 1904}

Localities and number of specimens: I (1) and III (15).

Remarks: Species with the type locality in Norway and recorded from many localities in the Northern Hemisphere from the Arctic to northern Africa (McInnes 1994) and only a few in the Southern Hemisphere in Argentina and Chile (Maucci 1988; Rossi et al. 2009; Roszkowska et al. 2016). Such distribution may suggest a species complex (Kaczmarek et al. 2015). However, we compared specimens attributed to this species from the Antarctic Peninsula, Argentina and Norway (Spitsbergen), and no morphological differences between these populations were observed.

Genus: Testechiniscus Kristensen, 1987

Testechiniscus meridionalis (Murray, 1906)

Localities and number of specimens: I (2). 
Fig. 5 a-f Bryodelphax olszanowskii sp. nov. (paratypes): a ventral side covered with fine "granulation", (PCM); b "granulation" and large dark granules visible on plates (PCM); c large granules on ventral plates (SEM); $\mathbf{d}$ fine, irregular granulation on ventral side (SEM); e dark granules simulating additional ventral plate in row III, arrow (PCM); f indistinct ventral plate, arrow (PCM) (PCM phase-contrast light microscope, SEM scanning electron microscopy)
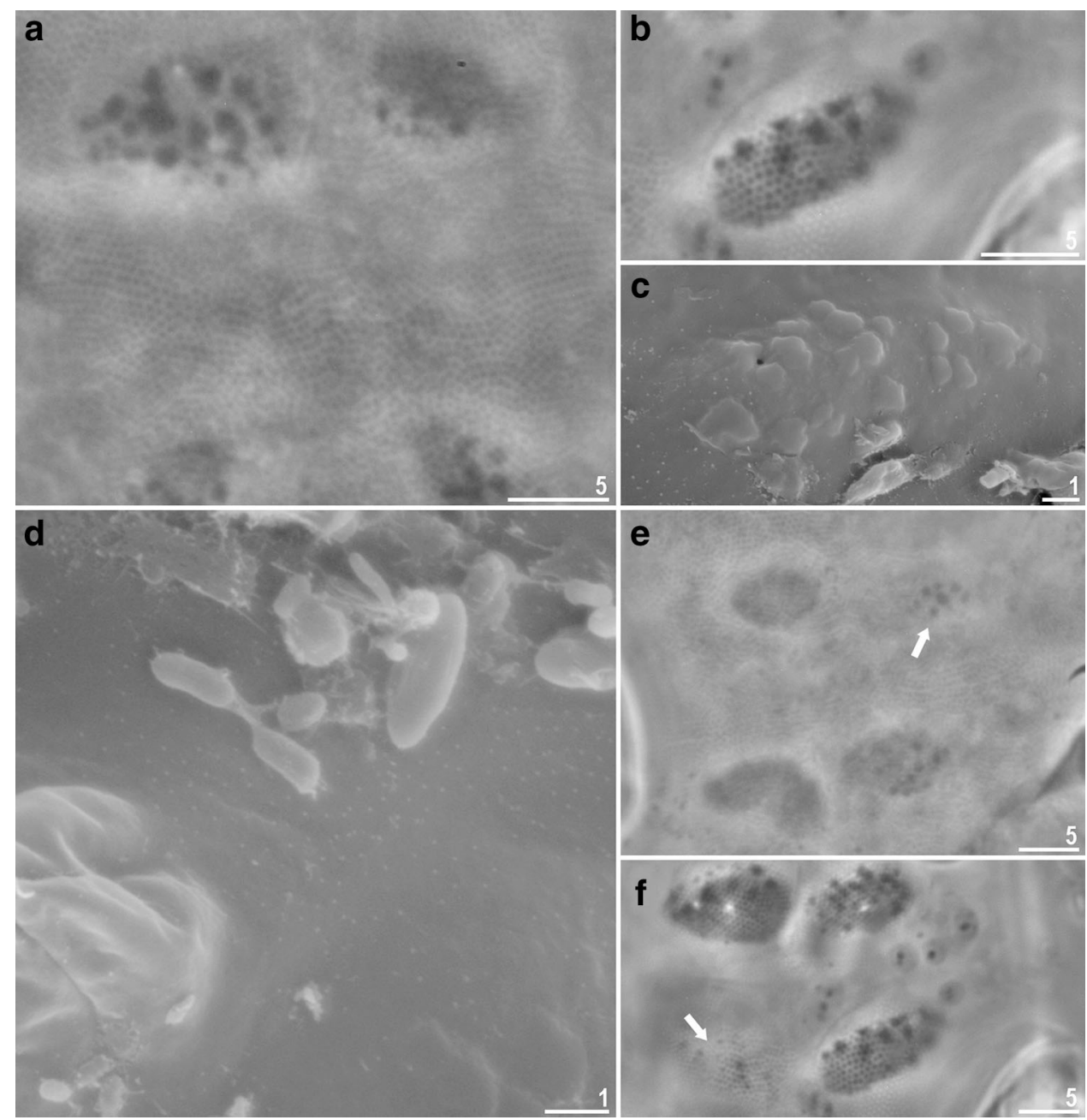

Remarks: Species widely distributed in the maritime Antarctic, known from the King George, South Orkney and South Shetland Islands (Dastych 1984, Convey and McInnes 2005).

Class: Eutardigrada Richters, 1926

Order: Parachela Schuster et al., 1980

Superfamily: HyPSIBIOIDEA Pilato, 1969

Family: HyPSIBIIDAe Pilato, 1969

Subfamily: Diphasconinae Dastych, 1992

Genus: Diphascon Plate, 1889

\section{Diphascon langhovdense (Sudzuki, 1964)}

Localities and number of specimens: I (3) and III (1).

Remarks: Species widely distributed in the continental and maritime Antarctic (Dastych 2002).

\section{Diphascon puchalskii sp. nov}

Material examined: type material: 54 animals (holotype and 53 paratypes) mounted on microscope slides in
Hoyer's medium; additional material: 9 specimens mounted on microscope slides in Hoyer's medium.

\section{Description of the new species}

Animals (measurements and statistics in Table 2)

Body white in adults, transparent after fixation in Hoyer's medium (Fig. 7a). Eyes absent. Dorsal and ventral cuticle smooth. Granulation on legs I-IV absent.

Mouth antero-ventral. Bucco-pharyngeal apparatus of the Diphascon type, a Diphascon variant (Fig. 8a). The oral cavity armature absent or not visible in LM. Buccopharyngeal divided into rigid buccal tube without annulations and long, flexible pharyngeal tube with very clearly visible annulations. A sclerified drop-shaped thickening between the rigid buccal tube and the flexible pharyngeal tube present.

Pharyngeal bulb oval with small triangular apophyses, three rod-shaped macroplacoids, small granular microplacoid and septulum (Fig. 8a). The macroplacoid length 

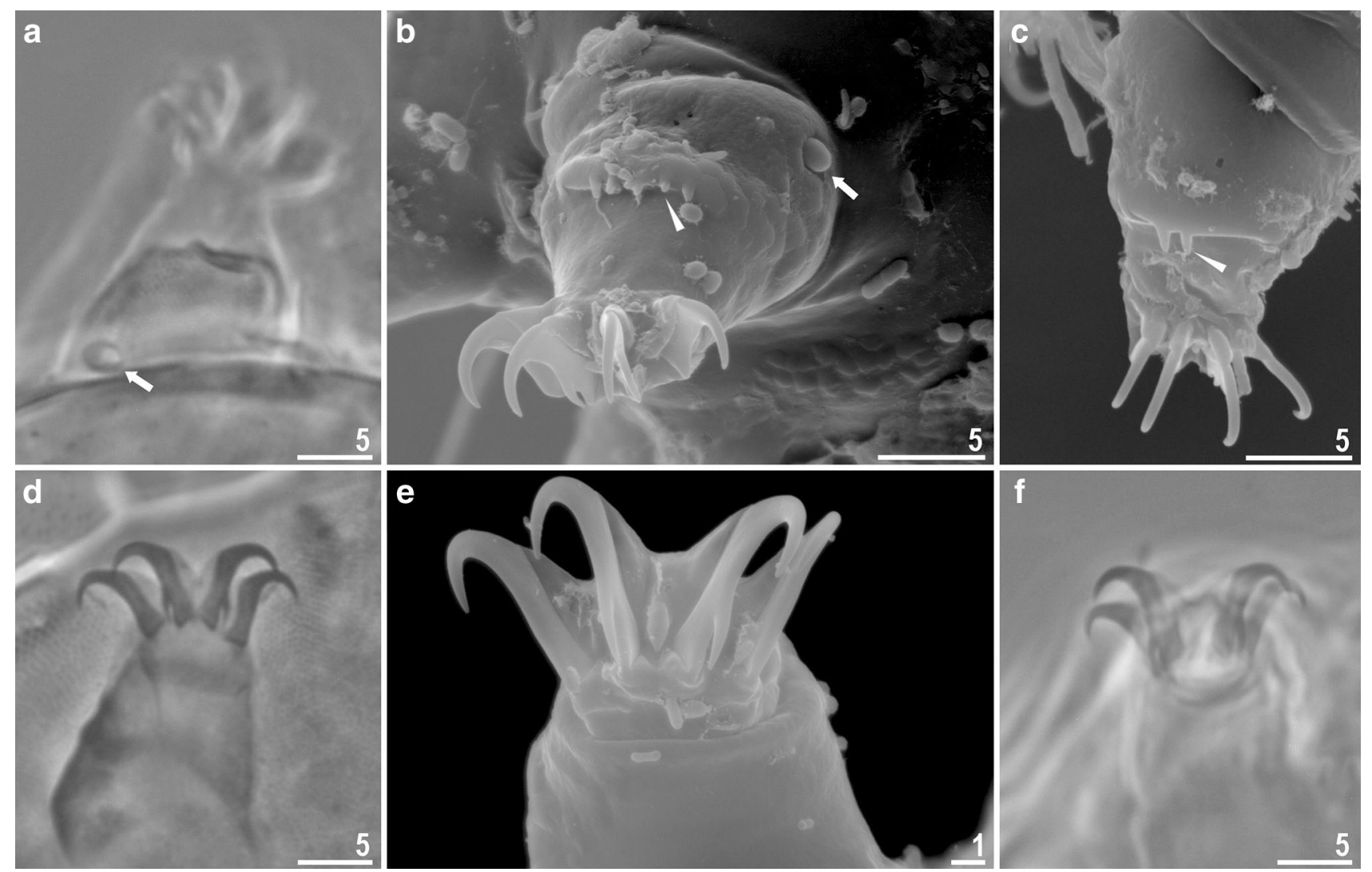

Fig. 6 a-f Bryodelphax olszanowskii sp. nov.: a papilla on leg IV (holotype, PCM); b-c poorly developed dentate collar on legs IV, arrowheads indicate dentate collar, arrow indicates papilla (paratype,

sequence $1 \leq 2<3$. All macroplacoids without central and terminal constrictions (Fig. 8a). The spaces between macroplacoids were clearly visible and more or less the same.

Claws of the Hypsibius type. Primary branches with distinct accessory points. Bars under claws absent. Claw bases not enlarged and without indentation. Lunules and other cuticular thickenings absent on all legs (Fig. 8c, e).

Eggs smooth deposited in exuvia.

Type locality: IV. $65^{\circ} 14.554^{\prime} \mathrm{S}, 64^{\circ} 16.431^{\prime} \mathrm{W}, 12 \mathrm{~m}$ asl, Argentine Islands, Central Island of Three Little Pigs group, L. dominicanus nest (bryophytes-85\%, lichens$1 \%$ of the entire nest material), date: 02.2014 , coll. Ivan Parnikoza.

Additional localities: I (1 specimen). $62^{\circ} 12.915^{\prime} \mathrm{S}$, $58^{\circ} 56.301^{\prime} \mathrm{W}, 0 \mathrm{~m}$ asl, Ardley Island, L. dominicanus nest (bryophytes-40\%, lichens-25\% of the entire nest material), date: 02.2015, coll. Jan Esefeld; III (8 specimens). $65^{\circ} 14.442^{\prime} \mathrm{S}, 64^{\circ} 15.286^{\prime} \mathrm{W}, 13 \mathrm{~m}$ asl, Argentine Islands, Grotto Island, L. dominicanus nest (bryophytes-61\%, lichens-20\%,D. antarctica-15\% of the entire nest material), date: 02.2014, coll. Ivan Parnikoza.
SEM); d claws of leg I (paratype, PCM); e-f claws of leg IV (paratype, SEM and PCM, respectively) (PCM phase-contrast light microscope, SEM scanning electron microscopy)

Etymology: We dedicate this species to a distinguished Polish nature photographer, Włodzimierz Puchalski, the author of many nature films and books and the famous phrase "bloodless hunt". He died during a scientific expedition to Antarctic and was buried in King George Island.

Type depositories: Holotype: slide AT54/4 (with eight paratypes) and 27 paratypes (slides: AT54/*, where the asterisk can be substituted by any of the following numbers: $1,3,5,6,9,13,15,16,17,18)$ are deposited at the Department of Animal Taxonomy and Ecology, Institute of Environmental Biology, Adam Mickiewicz University, Poznań, 13 paratypes (slide AT54/19) are deposited at the Zoological Museum, The Natural History Museum of Denmark, the University of Copenhagen, Universitetsparken 15, DK-2100 Copenhagen $\varnothing$, Denmark and five paratypes (slide AT54/14) are deposited at collection of Binda and Pilato, the Museum of the Department of Animal Biology 'Marcello La Greca', the University of Catania, Italy. 
Table 2 Measurements [in $\mu \mathrm{m}$ ] and ptd values of selected morphological structures of Diphascon puhalskii sp. nov. mounted in Hoyer's medium

\begin{tabular}{|c|c|c|c|c|c|c|c|c|c|c|c|c|c|}
\hline \multirow{3}{*}{$\begin{array}{l}\text { Character } \\
\text { Body length }\end{array}$} & \multirow{3}{*}{$\begin{array}{l}N \\
30\end{array}$} & \multicolumn{6}{|l|}{ Range } & \multicolumn{2}{|l|}{ Mean } & \multicolumn{2}{|l|}{ SD } & \multicolumn{2}{|c|}{ Holotype } \\
\hline & & \multicolumn{3}{|l|}{$\mu \mathrm{m}$} & \multicolumn{3}{|l|}{ ptd } & \multirow{2}{*}{$\frac{\mu \mathrm{m}}{253}$} & \multirow{2}{*}{$\frac{p t d}{-}$} & \multirow{2}{*}{$\frac{\mu \mathrm{m}}{28}$} & \multirow{2}{*}{$\frac{p t d}{-}$} & \multirow{2}{*}{$\frac{\mu \mathrm{m}}{276}$} & \multirow{2}{*}{$\frac{p t d}{-}$} \\
\hline & & 197 & - & 298 & & - & & & & & & & \\
\hline \multicolumn{14}{|l|}{ Buccopharyngeal tube } \\
\hline Buccal tube length & 30 & 19.3 & - & 26.0 & & - & & 22.7 & - & 1.6 & - & 22.3 & - \\
\hline Pharyngeal tube length & 28 & 32.0 & - & 45.0 & 150.6 & - & 188.7 & 38.0 & 167.7 & 3.7 & 11.7 & 39.7 & 178.0 \\
\hline Buccopharyngeal tube length & 28 & 52.2 & - & 69.3 & 250.6 & - & 288.3 & 60.6 & 267.5 & 5.0 & 11.4 & 62.0 & 278.0 \\
\hline Buccal/pharyngeal tube length ratio & 28 & $53.0 \%$ & - & $66.4 \%$ & & - & & $59.9 \%$ & - & $4.1 \%$ & - & $56.2 \%$ & - \\
\hline $\begin{array}{l}\text { Buccal/buccopharyngeal tube length } \\
\text { ratio }\end{array}$ & 28 & $34.7 \%$ & - & $39.9 \%$ & & & & $37.4 \%$ & & $1.6 \%$ & & $36.0 \%$ & \\
\hline Stylet support insertion point & 28 & 12.0 & - & 15.6 & 60.3 & - & 64.4 & 14.0 & 61.9 & 1.0 & 1.2 & 13.6 & 61.0 \\
\hline Buccal tube external width & 30 & 2.1 & - & 2.8 & 9.7 & - & 11.7 & 2.4 & 10.6 & 0.2 & 0.6 & 2.4 & 10.8 \\
\hline Buccal tube internal width & 30 & 0.8 & - & 1.3 & 3.6 & - & 5.2 & 1.0 & 4.3 & 0.1 & 0.4 & 0.9 & 4.0 \\
\hline \multicolumn{14}{|l|}{ Placoid lengths } \\
\hline Macroplacoid 1 & 30 & 2.9 & - & 4.9 & 13.7 & - & 20.7 & 3.8 & 16.9 & 0.5 & 1.5 & 4.1 & 18.4 \\
\hline Macroplacoid 2 & 30 & 3.3 & - & 5.2 & 15.4 & - & 20.7 & 4.0 & 17.8 & 0.5 & 1.4 & 4.3 & 19.3 \\
\hline Macroplacoid 3 & 30 & 5.2 & - & 7.7 & 24.6 & - & 32.0 & 6.4 & 28.1 & 0.7 & 1.9 & 6.6 & 29.6 \\
\hline Microplacoid & 28 & 0.7 & - & 1.2 & 3.3 & - & 5.2 & 1.0 & 4.2 & 0.2 & 0.6 & 1.0 & 4.5 \\
\hline Septulum & 30 & 2.4 & - & 3.2 & 10.4 & - & 13.8 & 2.8 & 12.4 & 0.2 & 0.9 & 2.6 & 11.7 \\
\hline Macroplacoid row & 30 & 12.6 & - & 18.7 & 59.7 & - & 74.6 & 15.2 & 67.1 & 1.6 & 4.2 & 15.6 & 70.0 \\
\hline Placoid row & 30 & 16.1 & - & 22.2 & 76.4 & - & 91.1 & 18.9 & 83.3 & 1.7 & 4.5 & 19.8 & 88.8 \\
\hline \multicolumn{14}{|l|}{ Claw 1 lengths } \\
\hline External primary branch & 16 & 9.2 & - & 13.3 & 45.7 & - & 55.0 & 11.4 & 50.4 & 1.0 & 2.5 & 11.1 & 49.8 \\
\hline External secondary branch & 15 & 5.7 & - & 8.8 & 26.4 & - & 36.4 & 6.8 & 30.3 & 0.8 & 2.5 & 6.1 & 27.4 \\
\hline Internal primary branch & 14 & 7.0 & - & 9.7 & 33.0 & - & 40.8 & 8.4 & 37.4 & 0.8 & 2.3 & 8.4 & 37.7 \\
\hline Internal secondary branch & 14 & 4.5 & - & 7.1 & 21.7 & - & 30.1 & 5.6 & 25.0 & 0.7 & 2.6 & 5.9 & 26.5 \\
\hline \multicolumn{14}{|l|}{ Claw 2 lengths } \\
\hline External primary branch & 19 & 10.6 & - & 15.5 & 51.7 & - & 68.3 & 13.3 & 58.6 & 1.3 & 4.8 & 13.9 & 62.3 \\
\hline External secondary branch & 18 & 6.0 & - & 8.9 & 27.0 & - & 36.8 & 7.3 & 32.5 & 0.7 & 2.5 & 6.7 & 30.0 \\
\hline Internal primary branch & 18 & 7.8 & - & 11.8 & 37.7 & - & 50.4 & 9.7 & 43.1 & 1.1 & 3.6 & 9.9 & 44.4 \\
\hline Internal secondary branch & 17 & 5.1 & - & 6.7 & 22.3 & - & 29.5 & 5.9 & 26.1 & 0.5 & 1.7 & 5.9 & 26.5 \\
\hline \multicolumn{14}{|l|}{ Claw 3 lengths } \\
\hline External primary branch & 26 & 10.7 & - & 15.9 & 52.4 & - & 69.0 & 13.3 & 58.7 & 1.2 & 4.6 & 13.8 & 61.9 \\
\hline External secondary branch & 22 & 6.0 & - & 9.5 & 29.1 & - & 37.8 & 7.7 & 34.0 & 1.0 & 2.8 & 7.5 & 33.6 \\
\hline Internal primary branch & 20 & 7.8 & - & 11.5 & 38.5 & - & 51.3 & 9.7 & 43.0 & 0.9 & 3.9 & 10.6 & 47.5 \\
\hline Internal secondary branch & 17 & 5.0 & - & 6.6 & 25.0 & - & 31.6 & 6.0 & 27.0 & 0.4 & 1.7 & 6.4 & 28.7 \\
\hline \multicolumn{14}{|l|}{ Claw 4 lengths } \\
\hline Anterior primary branch & 17 & 8.7 & - & 11.6 & 41.9 & - & 51.6 & 10.4 & 46.1 & 0.9 & 2.8 & 10.6 & 47.5 \\
\hline Anterior secondary branch & 14 & 5.3 & - & 7.5 & 26.0 & - & 31.0 & 6.3 & 28.5 & 0.5 & 1.7 & 6.2 & 27.8 \\
\hline Posterior primary branch & 15 & 12.1 & - & 16.8 & 59.3 & - & 76.7 & 14.8 & 66.1 & 1.4 & 5.6 & 16.3 & 73.1 \\
\hline Posterior secondary branch & 15 & 6.5 & - & 9.4 & 31.4 & - & 40.4 & 8.2 & 36.4 & 0.9 & 3.1 & 8.4 & 37.7 \\
\hline
\end{tabular}

$N$ number of specimens/structures measured, range refers to the smallest and the largest structure among all measured specimens, $S D$ standard deviation, ? trait oriented unsuitably for measurement, ptd the ratio of the length of a given structure to the length of the buccal tube expressed as a percentage 

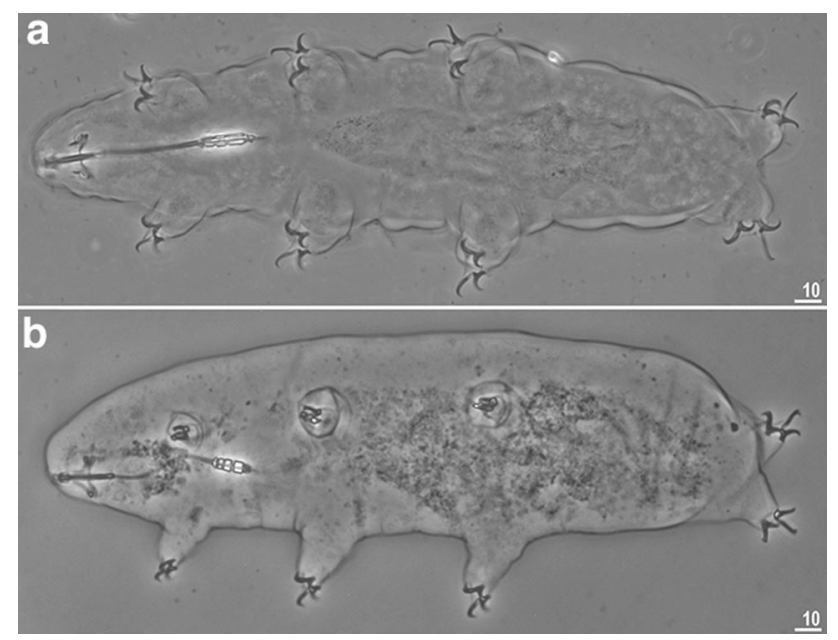

Fig. 7 a-b Habitus; dorso-ventral projection: a Diphascon puchalskii sp. nov. (holotype, PCM); b Diphascon rudnickii sp. nov. (holotype, PCM) (PCM phase-contrast light microscope)
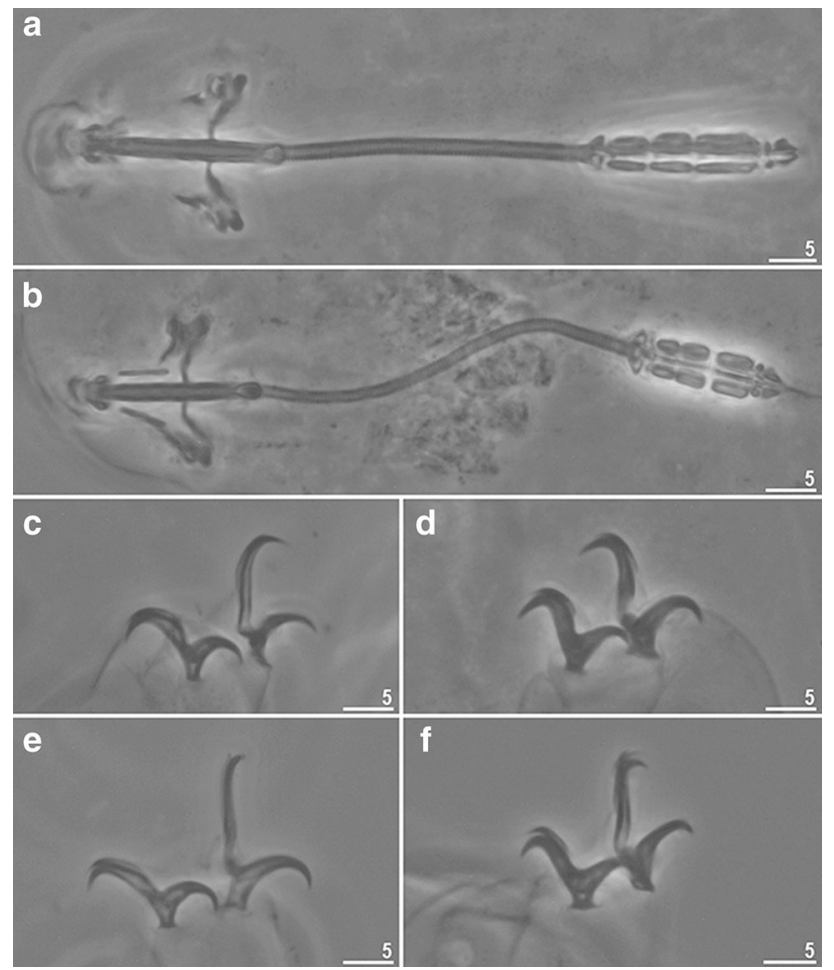

Fig. 8 a-f Diphascon puchalskii sp. nov.: a bucco-pharyngeal apparatus (holotype, PCM); b claws of leg II (holotype, PCM); c claws of leg IV (holotype, PCM); Diphascon rudnickii sp. nov.: d bucco-pharyngeal apparatus (holotype, PCM); e claws of leg II (paratype, PCM); f claws of leg IV (holotype, PCM) (PCM phasecontrast light microscope)

\section{Differential diagnosis}

The new species belongs to very homogenous pingue group (Pilato and Binda 1997/98; 1999), and it differs from the most similar D. victoriae Pilato and Binda, 1999, also known from Antarctica, only by some quantitative characters: the wider buccal tube $(2.1-2.8 \mu \mathrm{m}[p t d=9.7-11.7]$ in the new species vs. $1.7-1.9 \mu \mathrm{m}[p t d=6.5-7.6]$ in $D$. victoriae); larger ptd values of external claws II-III (51.769.0 in the new species vs. 45.7-46.7 in D. victoriae); larger ptd values of internal claws II-III (37.7-51.3 in the new species vs. $31.2-32.8$ in D. victoriae); and longer anterior and posterior claws IV $(8.7-11.6[p t d=41.9$ 51.6] and 12.1-16.8 [ptd $=59.3-76.7]$ in the new species vs. 7.7-8.5 [ptd $=30.8-34.1]$ and ca. $12.0[p t d=51.5]$ in D. victoriae).

\section{Diphascon rudnickii sp. nov}

Material examined: 45 animals (holotype and 44 paratypes) mounted on microscope slides in Hoyer's medium.

\section{Description of the new species}

\section{Animals (measurements and statistics in Table 3)}

Body white in adults, transparent after fixation in Hoyer's medium (Fig. 7b). Eyes absent. Dorsal and ventral cuticle smooth. Granulation on legs I-IV absent.

Mouth antero-ventral. Bucco-pharyngeal apparatus of the Diphascon type, a Diphascon variant (Fig. 8b). The oral cavity armature absent or not visible in LM. Buccopharyngeal divided into rigid buccal tube without annulations and long, flexible pharyngeal tube with clearly visible annulations. A sclerified drop-shaped thickening between the rigid buccal tube and the flexible pharyngeal tube present.

Pharyngeal bulb oval with small triangular apophyses, three rod-shaped macroplacoids, small granular microplacoid and septulum (Fig. 8b). The macroplacoid length sequence $1<2<3$. All macroplacoids without central constrictions (Fig. 8b). First macroplacoid situated extremely close to (in most cases touching) the second one. Therefore, these two macroplacoids look like one with a deep central constriction. Third macroplacoid situated at much larger distance.

Claws of the Hypsibius type. Primary branches with distinct accessory points. Bars under claws absent. Claw bases not enlarged and without indentation. Lunules and other cuticular thickenings absent on all legs (Fig. 8d, f).

Eggs smooth deposited in exuvia.

Type locality: I. $62^{\circ} 12.915^{\prime} \mathrm{S}, 58^{\circ} 56.301^{\prime} \mathrm{W}, 5 \mathrm{~m}$ asl, Ardley Island, L. dominicanus nest (bryophytes-40\%, lichens-25\% of the entire nest material), date: 02.2015 , coll. Jan Esefeld.

Etymology: We dedicate this species to the distinguished Ukrainian geographer, Prof. Stepan Rudnicki, who published one of the first papers on Antarctica in Ukrainian. 
Table 3 Measurements [in $\mu \mathrm{m}$ ] and ptd values of selected morphological structures of Diphascon rudnickii sp. nov. mounted in Hoyer's medium

\begin{tabular}{|c|c|c|c|c|c|c|c|c|c|c|c|c|c|}
\hline \multirow{3}{*}{$\begin{array}{l}\text { Character } \\
\text { Body length }\end{array}$} & \multirow{3}{*}{$\begin{array}{l}N \\
30\end{array}$} & \multicolumn{6}{|l|}{ Range } & \multicolumn{2}{|l|}{ Mean } & \multicolumn{2}{|l|}{ SD } & \multicolumn{2}{|c|}{ Holotype } \\
\hline & & \multicolumn{3}{|l|}{$\mu \mathrm{m}$} & \multicolumn{3}{|l|}{ ptd } & \multirow{2}{*}{$\frac{\mu \mathrm{m}}{259}$} & \multirow{2}{*}{$\frac{p t d}{-}$} & \multirow{2}{*}{$\frac{\mu \mathrm{m}}{30}$} & \multirow{2}{*}{$\frac{p t d}{-}$} & \multirow{2}{*}{$\frac{\mu \mathrm{m}}{279}$} & \multirow{2}{*}{$\frac{p t d}{-}$} \\
\hline & & 206 & - & 323 & & - & & & & & & & \\
\hline \multicolumn{14}{|l|}{ Buccopharyngeal tube } \\
\hline Buccal tube length & 30 & 19.0 & - & 25.9 & & - & & 22.0 & - & 1.9 & - & 21.6 & - \\
\hline Pharyngeal tube length & 28 & 35.5 & - & 53.1 & 179.0 & - & 221.5 & 43.1 & 196.2 & 4.7 & 11.8 & 41.7 & 193.1 \\
\hline Buccopharyngeal tube length & 28 & 54.7 & - & 78.5 & 279.0 & - & 320.0 & 65.0 & 296.0 & 6.4 & 11.1 & 63.3 & 293.1 \\
\hline Buccal/pharyngeal tube length ratio & 28 & $45.1 \%$ & - & $55.9 \%$ & & - & & $51.1 \%$ & - & $3.0 \%$ & - & $51.8 \%$ & - \\
\hline $\begin{array}{l}\text { Buccal/buccopharyngeal tube length } \\
\text { ratio }\end{array}$ & 28 & $31.3 \%$ & - & $35.8 \%$ & & - & & $33.8 \%$ & - & $1.3 \%$ & - & $34.1 \%$ & - \\
\hline Stylet support insertion point & 30 & 10.5 & - & 14.6 & 54.7 & - & 57.6 & 12.4 & 56.3 & 1.1 & 0.8 & 12.0 & 55.6 \\
\hline Buccal tube external width & 30 & 1.6 & - & 2.2 & 7.9 & - & 10.0 & 1.9 & 8.6 & 0.2 & 0.5 & 1.9 & 8.8 \\
\hline Buccal tube internal width & 27 & 0.6 & - & 1.0 & 2.5 & - & 4.1 & 0.8 & 3.5 & 0.1 & 0.4 & 0.8 & 3.7 \\
\hline \multicolumn{14}{|l|}{ Placoid lengths } \\
\hline Macroplacoid 1 & 28 & 1.9 & - & 3.0 & 9.8 & - & 12.6 & 2.4 & 11.0 & 0.3 & 0.8 & 2.4 & 11.1 \\
\hline Macroplacoid 2 & 28 & 2.3 & - & 3.4 & 12.0 & - & 14.6 & 2.8 & 13.0 & 0.3 & 0.7 & 2.8 & 13.0 \\
\hline Macroplacoid 3 & 28 & 2.7 & - & 4.2 & 13.8 & - & 17.7 & 3.5 & 16.1 & 0.4 & 1.0 & 3.7 & 17.1 \\
\hline Microplacoid & 26 & 0.7 & - & 1.2 & 3.2 & - & 5.1 & 0.9 & 4.1 & 0.1 & 0.5 & 0.7 & 3.2 \\
\hline Septulum & 28 & 1.5 & - & 2.5 & 7.5 & - & 9.7 & 1.9 & 8.8 & 0.2 & 0.6 & 1.8 & 8.3 \\
\hline Macroplacoid row & 28 & 7.6 & - & 12.7 & 38.8 & - & 49.0 & 9.8 & 44.4 & 1.2 & 2.8 & 9.7 & 44.9 \\
\hline Placoid row & 28 & 10.0 & - & 16.1 & 51.0 & - & 63.4 & 12.6 & 57.5 & 1.5 & 3.2 & 12.7 & 58.8 \\
\hline \multicolumn{14}{|l|}{ Claw 1 lengths } \\
\hline External primary branch & 16 & 7.3 & - & 11.7 & 38.0 & - & 50.0 & 9.3 & 43.2 & 1.1 & 3.2 & 9.2 & 42.6 \\
\hline External secondary branch & 15 & 5.0 & - & 6.9 & 24.3 & - & 32.1 & 5.8 & 27.4 & 0.6 & 2.4 & 5.7 & 26.4 \\
\hline Internal primary branch & 15 & 5.8 & - & 8.4 & 29.7 & - & 35.4 & 6.9 & 32.2 & 0.7 & 1.8 & 6.9 & 31.9 \\
\hline Internal secondary branch & 14 & 3.1 & - & 5.9 & 16.1 & - & 24.9 & 4.6 & 21.6 & 0.7 & 2.6 & 3.8 & 17.6 \\
\hline \multicolumn{14}{|l|}{ Claw 2 lengths } \\
\hline External primary branch & 20 & 9.2 & - & 13.5 & 43.2 & - & 53.9 & 10.8 & 49.4 & 1.3 & 2.8 & 10.4 & 48.1 \\
\hline External secondary branch & 19 & 5.0 & - & 7.9 & 24.5 & - & 33.2 & 6.5 & 29.8 & 0.9 & 2.6 & 5.3 & 24.5 \\
\hline Internal primary branch & 23 & 7.0 & - & 10.0 & 32.4 & - & 39.5 & 8.1 & 37.0 & 0.8 & 1.9 & 7.7 & 35.6 \\
\hline Internal secondary branch & 21 & 4.5 & - & 6.6 & 21.0 & - & 30.5 & 5.4 & 24.7 & 0.7 & 2.1 & 4.9 & 22.7 \\
\hline \multicolumn{14}{|l|}{ Claw 3 lengths } \\
\hline External primary branch & 19 & 9.3 & - & 14.0 & 44.9 & - & 56.3 & 11.3 & 51.4 & 1.2 & 2.8 & 10.8 & 50.0 \\
\hline External secondary branch & 20 & 4.9 & - & 8.1 & 25.0 & - & 37.1 & 6.7 & 30.4 & 0.9 & 2.7 & 5.8 & 26.9 \\
\hline Internal primary branch & 21 & 7.1 & - & 10.1 & 33.9 & - & 41.8 & 8.5 & 38.4 & 0.9 & 2.3 & 8.1 & 37.5 \\
\hline Internal secondary branch & 19 & 4.3 & - & 7.2 & 22.4 & - & 30.0 & 5.7 & 25.8 & 0.7 & 2.2 & 5.3 & 24.5 \\
\hline \multicolumn{14}{|l|}{ Claw 4 lengths } \\
\hline Anterior primary branch & 23 & 6.9 & - & 10.8 & 35.9 & - & 45.0 & 9.0 & 41.1 & 0.9 & 2.5 & 9.2 & 42.6 \\
\hline Anterior secondary branch & 22 & 5.1 & - & 8.2 & 26.6 & - & 35.0 & 6.5 & 30.0 & 0.8 & 2.2 & 6.4 & 29.6 \\
\hline Posterior primary branch & 21 & 11.0 & - & 15.4 & 55.8 & - & 66.7 & 13.3 & 60.9 & 1.1 & 3.3 & 13.5 & 62.5 \\
\hline Posterior secondary branch & 21 & 6.0 & - & 9.0 & 30.1 & - & 42.3 & 7.7 & 35.2 & 0.8 & 2.7 & 7.8 & 36.1 \\
\hline
\end{tabular}

$N$ number of specimens/structures measured, range refers to the smallest and the largest structure among all measured specimens; $S D$ standard deviation, ? trait oriented unsuitably for measurement, ptd the ratio of the length of a given structure to the length of the buccal tube expressed as a percentage)

Type depositories: Holotype: slide AT49/6 (with two paratypes) and 25 paratypes (slides: AT49/*, where the asterisk can be substituted by any of the following numbers: $7,8,10,12,14)$ are deposited at the Department of
Animal Taxonomy and Ecology, the Institute of Environmental Biology, Adam Mickiewicz University, Poznań; 11 paratypes (slide AT49/3) are deposited at the Zoological Museum, the Natural History Museum of Denmark, the 
University of Copenhagen, Universitetsparken 15, DK2100 Copenhagen $\varnothing$, Denmark; and six paratypes (slide AT49/4) are deposited at collection centre of Binda and Pilato, the Museum of the Department of Animal Biology 'Marcello La Greca', the University of Catania, Italy.

\section{Differential diagnosis}

The new species belongs to very homogenous pingue group (Pilato and Binda 1997/98, 1999) but differs from all species in this group by having the first and second macroplacoids situated extremely close to each other (in most cases touching). Moreover, Diphascon rudnickii sp. nov. differs from the most similar, according to morphometry, D. polare Pilato and Binda, 1999, also known from Antarctica by having: fully and uniformly sclerotized drop-shaped thickening (drop-shaped thickening not uniformly sclerotized, more sclerotized in median portion and caudal margin in $D$. polare), smaller body length (206-323 $\mu \mathrm{m}$ in the new species $v s .339-387 \mu \mathrm{m}$ in $D$. polare), lower ptd of stylet support insertion point (54.7$57.6 \mu \mathrm{m}$ in the new species vs. $61.1-62.8 \mu \mathrm{m}$ in D. polare), and shorter posterior claws IV (11.0-15.4 $\mu \mathrm{m}$ in the new species vs. $16.6-19.5 \mu \mathrm{m}$ in D. polare).

Subfamily: HyPSIBIINAE Pilato, 1969

Genus: Hypsibius Ehrenberg, 1848

\section{Hypsibius conwentzii sp. nov}

Material examined: 23 animals (holotype and 22 paratypes) mounted on microscope slides in Hoyer's medium.

\section{Description of the new species}

Animals (measurements and statistics in Table 4) Body white in adults, transparent after fixation in Hoyer's medium (Fig. 9a). Eyes present, very large (but, see also Remarks below) (Fig. 9b). Dorsal and ventral cuticle smooth. Granulation on legs I-IV absent (Fig. 10a-d).

Mouth antero-ventral. Bucco-pharyngeal apparatus of the Hypsibius type, a Hypsibius variant (Fig. 34). The oral cavity armature absent or not visible in LM (Fig. 9b).

Pharyngeal bulb roundish with triangular apophyses, two rod-shaped macroplacoids and large septulum (Fig. 9b). The macroplacoid length sequence $1>2$. First macroplacoid with very shallow central constriction, second one without constrictions (Fig. 9b).

Claws of the Hypsibius type (Figs. 10a-d). Primary branches with distinct accessory points (Fig. 10d). A thick cuticular bars present along the proximal side of the internal claws I-III and between anterior and posterior claws IV (but see also Remarks below) (Figs. 10a-e). Claw bases distinctly enlarged, especially on legs IV, but not indented and without lunules (Fig. 10a-d).

Eggs smooth deposited in exuvia.

Remarks: Among all the examined individuals, the eyes were absent in only one specimen, which probably was in the moulting process. In some, especially smaller individuals, the bars near internal claws I-III were barely visible. Moreover, in some orientations of the claws, the bars can be completely invisible, even those between anterior and posterior claws IV. In addition, in a few examples, short cuticular bars were also observed between internal and external claws I-III.

Type locality: I. $62^{\circ} 12.915^{\prime} \mathrm{S}, 58^{\circ} 56.301^{\prime} \mathrm{W}, 5 \mathrm{~m}$ asl, Ardley Island, L. dominicanus nest (bryophytes-40\%, lichens-25\% of the entire nest material), date: 02.2015 , coll. Jan Esefeld.

Etymology: We dedicate this species to the distinguished German botanist and archaeologist, Hugo Wilhelm Conwentz, pioneer of European nature conservation (also in Antarctica) and promoter of the idea of National Parks. $\mathrm{He}$ also authored the idea of the creation of a strictly protected area in Antarctica.

Type depositories: Holotype: slide AT49/12 (with two paratypes) and seven paratypes (slides: AT49/*, where the asterisk can be substituted by any of the following numbers: $6,7,8,9,10,14)$ are deposited at the Department of Animal Taxonomy and Ecology, the Institute of Environmental Biology, Adam Mickiewicz University, Poznań; 10 paratypes (slide AT49/3) are deposited at the Zoological Museum, The Natural History Museum of Denmark, the University of Copenhagen, Universitetsparken 15, DK2100 Copenhagen $\varnothing$, Denmark; and three paratypes (slide AT49/4) are deposited at collection of Binda and Pilato, the Museum of the Department of Animal Biology 'Marcello La Greca', the University of Catania, Italy.

\section{Differential diagnosis}

The new species is most similar to $H$. dujardini (Doyère, 1840); H. heardensis Miller, McInnes and Bergstrom, 2005; H. iskandarovi Tumanov, 1997; H. septulatus Pilato, Binda, Napolitano and Moncada, 2004; H. seychellensis Pilato, Binda and Lisi, 2006; and H. valentinae Pilato, Kiosya, Lisi and Sabella, 2012; but it differs specifically from

1. H. dujardini, by buccal tube with the same width along its length (buccal tube with gradually increasing width along its length in $H$. dujardini), the presence of cuticular bars near the claws I-III, lower $p t$ of the stylet supports insertion points (59.9, in specimen $276 \mu \mathrm{m}$, in the new species vs. 64.1 , in specimen $274 \mu \mathrm{m}$, in $H$. 
Table 4 Measurements [in $\mu \mathrm{m}$ ] and pt values of selected morphological structures of Hypsibius conwentzii sp. nov. mounted in Hoyer's medium

\begin{tabular}{|c|c|c|c|c|c|c|c|c|c|c|c|c|c|}
\hline \multirow{3}{*}{$\begin{array}{l}\text { Character } \\
\text { Body length }\end{array}$} & \multirow{3}{*}{$\begin{array}{l}N \\
23\end{array}$} & \multicolumn{6}{|c|}{ Range } & \multicolumn{2}{|l|}{ mean } & \multicolumn{2}{|l|}{ SD } & \multicolumn{2}{|c|}{ Holotype } \\
\hline & & \multicolumn{3}{|l|}{$\mu \mathrm{m}$} & \multicolumn{3}{|l|}{$p t$} & \multirow{2}{*}{$\frac{\mu \mathrm{m}}{249}$} & \multirow{2}{*}{$\frac{p t}{-}$} & \multirow{2}{*}{$\frac{\mu \mathrm{m}}{32}$} & \multirow{2}{*}{$\frac{p t}{-}$} & \multirow{2}{*}{$\frac{\mu \mathrm{m}}{280}$} & \multirow{2}{*}{$\frac{p t}{-}$} \\
\hline & & 182 & - & 308 & & - & & & & & & & \\
\hline \multicolumn{14}{|l|}{ Buccal tube } \\
\hline Buccal tube length & 23 & 20.9 & - & 28.6 & & - & & 25.5 & - & 2.0 & - & 28.1 & - \\
\hline $\begin{array}{l}\text { Stylet support insertion } \\
\text { point }\end{array}$ & 23 & 12.4 & - & 17.2 & 58.6 & - & 62.4 & 15.4 & 60.3 & 1.4 & 1.2 & 17.2 & 61.2 \\
\hline Buccal tube external width & 23 & 2.0 & - & 2.8 & 8.7 & - & 11.2 & 2.6 & 10.1 & 0.2 & 0.6 & 2.8 & 10.0 \\
\hline Buccal tube internal width & 23 & 0.7 & - & 1.3 & 3.1 & - & 4.7 & 1.1 & 4.1 & 0.1 & 0.4 & 1.0 & 3.6 \\
\hline \multicolumn{14}{|l|}{ Placoid lengths } \\
\hline Macroplacoid 1 & 23 & 3.1 & - & 4.9 & 14.4 & - & 17.8 & 4.2 & 16.4 & 0.5 & 1.0 & 4.6 & 16.4 \\
\hline Macroplacoid 2 & 23 & 2.6 & - & 4.0 & 11.8 & - & 15.4 & 3.5 & 13.5 & 0.4 & 0.8 & 3.9 & 13.9 \\
\hline Septulum & 23 & 1.8 & - & 2.6 & 7.6 & - & 10.2 & 2.2 & 8.8 & 0.2 & 0.8 & 2.4 & 8.5 \\
\hline Macroplacoid row & 23 & 6.5 & - & 10.1 & 31.0 & - & 37.2 & 8.7 & 34.1 & 0.9 & 1.7 & 9.9 & 35.2 \\
\hline Placoid row & 23 & 8.8 & - & 13.3 & 40.2 & - & 48.0 & 11.5 & 45.1 & 1.2 & 2.1 & 13.3 & 47.3 \\
\hline \multicolumn{14}{|l|}{ Claw 1 lengths } \\
\hline External base & 17 & 3.4 & - & 5.5 & 16.1 & - & 20.4 & 4.6 & 18.1 & 0.6 & 1.2 & 5.2 & 18.5 \\
\hline External primary branch & 17 & 4.9 & - & 10.1 & 23.4 & - & 36.5 & 7.8 & 30.5 & 1.3 & 3.3 & 8.9 & 31.7 \\
\hline External secondary branch & 17 & 4.4 & - & 6.8 & 19.2 & - & 24.5 & 5.6 & 22.0 & 0.7 & 1.7 & 6.0 & 21.4 \\
\hline Internal base & 17 & 3.0 & - & 4.8 & 13.3 & - & 17.7 & 3.9 & 15.4 & 0.5 & 1.3 & 4.8 & 17.1 \\
\hline Internal primary branch & 17 & 4.5 & - & 7.4 & 19.5 & - & 26.7 & 6.0 & 23.6 & 0.9 & 2.3 & 6.5 & 23.1 \\
\hline Internal secondary branch & 17 & 3.1 & - & 4.9 & 14.0 & - & 18.1 & 4.1 & 15.9 & 0.6 & 1.4 & 4.9 & 17.4 \\
\hline \multicolumn{14}{|l|}{ Claw 2 lengths } \\
\hline External base & 22 & 3.6 & - & 5.9 & 17.2 & - & 22.0 & 5.0 & 19.4 & 0.6 & 1.3 & 5.8 & 20.6 \\
\hline External primary branch & 22 & 4.6 & - & 11.3 & 22.0 & - & 41.9 & 8.7 & 33.7 & 1.7 & 5.0 & 11.3 & 40.2 \\
\hline External secondary branch & 22 & 3.9 & - & 7.2 & 18.7 & - & 26.5 & 6.0 & 23.4 & 0.9 & 2.3 & 7.2 & 25.6 \\
\hline Internal base & 21 & 3.2 & - & 5.3 & 14.4 & - & 18.8 & 4.4 & 17.2 & 0.6 & 1.3 & 5.1 & 18.1 \\
\hline Internal primary branch & 22 & 5.1 & - & 8.8 & 24.4 & - & 33.5 & 7.3 & 28.7 & 1.0 & 2.5 & 8.6 & 30.6 \\
\hline Internal secondary branch & 21 & 3.4 & - & 5.9 & 16.3 & - & 24.1 & 4.9 & 19.3 & 0.8 & 2.1 & 5.7 & 20.3 \\
\hline \multicolumn{14}{|l|}{ Claw 3 lengths } \\
\hline External base & 18 & 3.8 & - & 6.5 & 17.5 & - & 23.1 & 5.3 & 20.3 & 0.8 & 1.8 & 6.2 & 22.1 \\
\hline External primary branch & 18 & 5.2 & - & 11.4 & 24.9 & - & 43.1 & 9.1 & 35.2 & 1.7 & 4.9 & 10.7 & 38.1 \\
\hline External secondary branch & 17 & 3.9 & - & 8.1 & 18.7 & - & 28.8 & 6.3 & 24.4 & 1.0 & 2.7 & 8.1 & 28.8 \\
\hline Internal base & 21 & 3.2 & - & 5.5 & 14.4 & - & 19.6 & 4.5 & 17.5 & 0.7 & 1.6 & 5.5 & 19.6 \\
\hline Internal primary branch & 21 & 5.2 & - & 9.0 & 24.7 & - & 35.5 & 7.4 & 29.1 & 1.0 & 2.9 & 8.3 & 29.5 \\
\hline Internal secondary branch & 20 & 3.3 & - & 6.2 & 15.8 & - & 23.5 & 4.9 & 19.3 & 0.8 & 2.1 & 6.2 & 22.1 \\
\hline \multicolumn{14}{|l|}{ Claw 4 lengths } \\
\hline Anterior base & 16 & 2.9 & - & 6.2 & 13.9 & - & 22.4 & 4.7 & 18.2 & 1.0 & 2.6 & 5.8 & 20.6 \\
\hline Anterior primary branch & 16 & 4.9 & - & 8.7 & 22.4 & - & 30.7 & 7.0 & 27.5 & 1.1 & 2.5 & 8.4 & 29.9 \\
\hline Anterior secondary branch & 15 & 3.0 & - & 7.2 & 14.4 & - & 25.2 & 5.2 & 20.3 & 1.1 & 2.8 & 6.7 & 23.8 \\
\hline Posterior base & 15 & 3.5 & - & 6.5 & 15.3 & - & 22.7 & 5.0 & 19.7 & 1.0 & 2.2 & 6.3 & 22.4 \\
\hline Posterior primary branch & 20 & 6.3 & - & 12.8 & 30.1 & - & 47.8 & 10.3 & 40.5 & 1.8 & 4.5 & 12.4 & 44.1 \\
\hline Posterior secondary branch & 20 & 4.3 & - & 8.0 & 20.6 & - & 28.6 & 6.5 & 25.5 & 1.0 & 2.3 & 8.0 & 28.5 \\
\hline
\end{tabular}

$N$ number of specimens/structures measured, range refers to the smallest and the largest structure among all measured specimens, $S D$ standard deviation, ? trait oriented unsuitably for measurement, $p t$ the ratio of the length of a given structure to the length of the buccal tube expressed as a percentage

dujardini), smaller macroplacoid I $\quad(4.7 \mu \mathrm{m}$ $[p t=17.0]$, in specimen $276 \mu \mathrm{m}$, in the new species vs. $6.0 \mu \mathrm{m}[p t=23.8]$, in specimen $274 \mu \mathrm{m}$, in $H$. dujardini), smaller macroplacoid II $(3.6 \mu \mathrm{m}$ [pt $=13.0]$, in specimen $276 \mu \mathrm{m}$, in the new species vs. $4.5 \mu \mathrm{m}[p t=17.8]$, in specimen $274 \mu \mathrm{m}$, in $H$. 
Fig. 9 a-b Hypsibius conwentzii sp. nov. (holotype, PCM): a ventral projection; b bucco-pharyngeal apparatus, arrowhead indicates central constriction of the first macroplacoid (PCM phasecontrast light microscope)
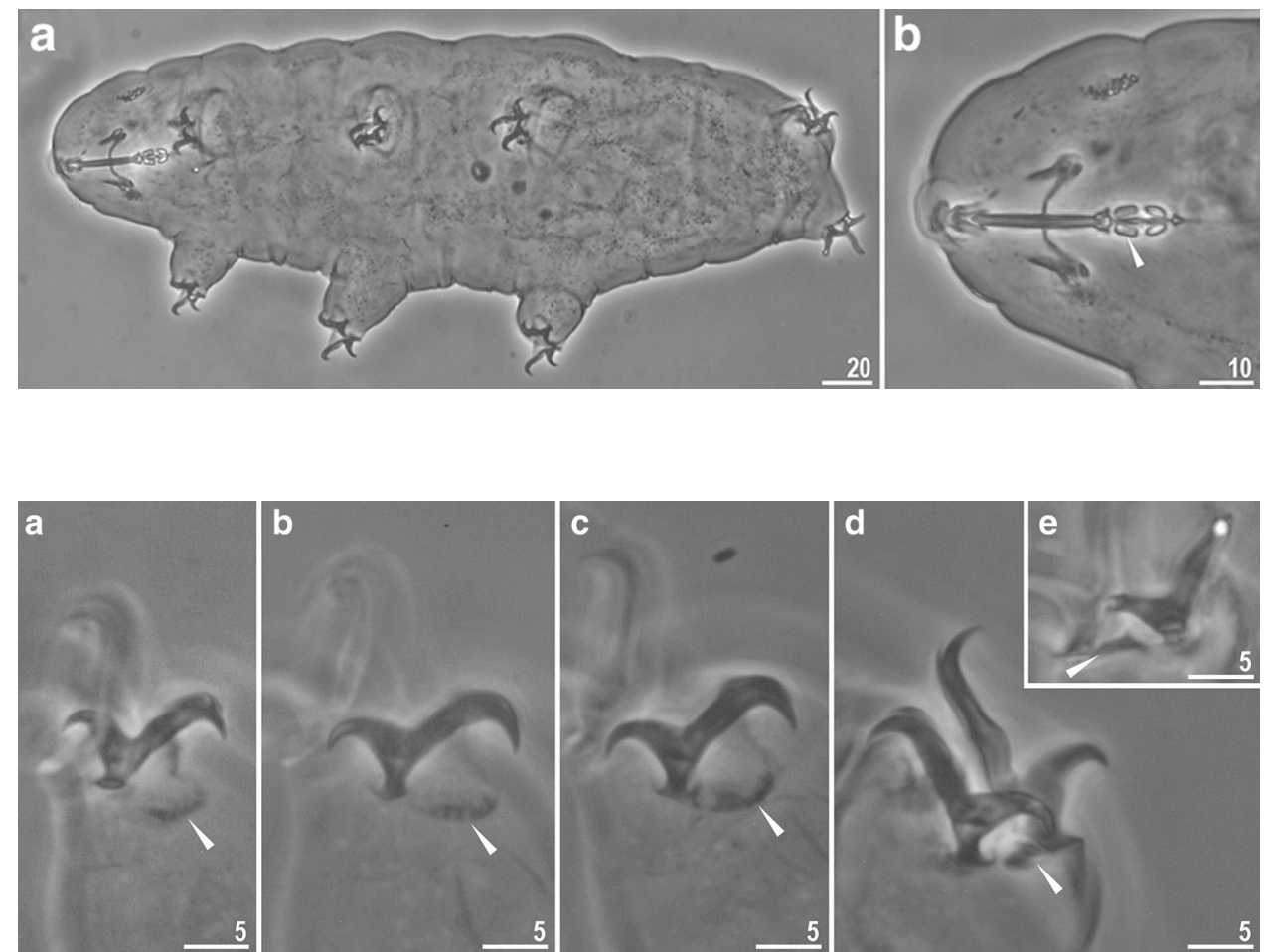

Fig. 10 a-e Hypsibius conwentzii sp. nov. claws (PCM): a claws of leg I, arrowhead indicates cuticular bar (holotype); b claws of leg II, arrowhead indicates cuticular bar (holotype); c claws of leg III, arrowhead indicates cuticular bar (holotype); d claws of leg IV, $\boldsymbol{e}$ cuticular bar on leg IV (paratype) ( $P C M$ phasecontrast light microscope) dujardini), shorter macroplacoid row $(10.0 \mu \mathrm{m}$ $[p t=36.1]$, in specimen $276 \mu \mathrm{m}$, in the new species vs. $11.0 \mu \mathrm{m}[p t=43.6]$, in specimen $274 \mu \mathrm{m}$, in $H$. dujardini) and shorter placoid row $(13.3 \mu \mathrm{m}$ [pt $=48.0$ ], in specimen $276 \mu \mathrm{m}$, in the new species vs. $13.8 \mu \mathrm{m}[p t=54.8]$, in specimen $274 \mu \mathrm{m}$, in $H$. dujardini).

2. H. heardensis, by the presence of large eyes, larger septulum $(1.8-2.6 \mu \mathrm{m}$ in the new species vs. $0.5-1.0 \mu \mathrm{m}$ in $H$. heardensis) and smooth cuticular bars (ragged in $H$. heardensis).

3. H. iskandarovi, by the absence of pseudoseptulum and lunules under claws.

4. H. septulatus, by the absence of dorsal undulations and cuticular bars near anterior claws IV, lower $p t$ of the stylet supports insertion points (58.6-62.4 in the new species vs. ca. 64.5 in $H$. septulatus), slightly lower $p t$ of the macroplacoid row length (31.0-37.2 in the new species vs. ca. 37.6 in $H$. septulatus) and slightly lower $p t$ of the placoid row length (40.2-48.0 in the new species vs. ca. 49.8 in $H$. septulatus).

5. H. seychellensis, by the presence of cuticular bars near the claws I-III.

6. H. valentinae, by the presence of cuticular bars near the claws I-III, the absence of lunules under claws, larger septulum $(1.8-2.6 \mu \mathrm{m}[p t=7.6-10.2]$ in the new species vs. $1.2-1.4 \mu \mathrm{m}[p t=4.4-5.1]$ in $H$. valentinae), shorter first macroplacoid (3.1-4.9 $\mu \mathrm{m}$ $[p t=14.4-17.8]$ in the new species vs. 5.1-6.0 $\mu \mathrm{m}$ $[p t=20.6-22.1]$ in $H$. valentinae $)$ and lower $p t$ of second macroplacoid (11.8-15.4 in the new species vs.15.7-17.0 in $H$. valentinae).

Subfamily: Itaquasconinae Rudescu, 1964

Genus: Adropion Pilato, 1987

\section{Adropion greveni (Dastych, 1984)}

Localities and number of specimens: I (1).

Remarks: In the Antarctic region species known from Alexander Island, Graham Land, King George Island, Marguerite Bay, South Georgia Island and South Orkney Island (Dastych 1984, Convey and McInnes 2005).

Incerta subfamilia \{according to Bertolani et al. 2014\}

Genus: Acutuncus Pilato and Binda, 1997

Acutuncus antarcticus (Richters, 1904)

Localities and number of specimens: I (13), III (3) and IV (1).

Remarks: The most widely distributed species in Antarctic region (Convey and McInnes 2005, Kaczmarek et al. 2014a).

Family: Ramazzottiidae Sands et al., 2008

Genus: Ramajendas Pilato and Binda, 1990 


\section{Ramajendas sp}

Localities and number of specimens: III (2)

Remarks: This species is probably new for science, but we found only two specimens, which precludes the formal description of a new taxon, especially since it differs from $R$. frigidus Pilato and Binda, 1990 and $R$. renaudi (Ramazzotti, 1972) only by some morphometric characters.

Superfamily: MACROBIOTOIDEA Thulin, 1928

Family: Macrobiotidae Thulin, 1928

Genus: Mesobiotus Vecchi et al., 2016

Mesobiotus aradasi (Binda, Pilato and Lisi, 2005)

Localities and number of specimens: I (37 animals +18 eggs), II (1), III (36), IV (220 + 111), V (10), VI $(51+6)$ and VII $(9+5)$.

Remarks: These are first records of this species beyond of its type locality on King George Island (Binda et al. 2005).

Genus: Minibiotus Schuster, 1980

Minibiotus vinciguerrae Binda and Pilato, 1992

Localities and number of specimens: VI (1).

Remarks: This is a first-ever record of this species beyond its type locality on Victoria Land (Binda and Pilato 1992).

\section{Discussion}

Birds in maritime Antarctic are some of the most important animals responsible for translocation of various parts of terrestrial vegetation (like bryophytes, lichens, algae and vascular plants) for shorter and longer distances. The birds that play a major role in plant transport are the kelp gull $(L$. dominicanus) and skua species (Stercorarius antarcticus (Lesson, 1831), S. maccormicki (Saunders, 1893), according to Parnikoza et al. $(2009,2012)$. The origin of transferred material is a very important question to explain the source of TARDIGRADA in nests. Bryophytes are the most common building material in the nests of these species. In kelp gull nests on Argentine Islands, the dominant moss species is Sanionia georgicouncinata (Müll. Hal.) Ochyra and Hedenäs. On Fildes Peninsula and Ardley Island (near King George Island), the dominant moss is $S$. uncinata (Hedw.) Loeske. These are ground-cover mosses, very common in communities of moss carpet sub-formation (Lindsay 1971; Smith and Corner 1973; Furmańczyk and Ochyra 1982) and are widely distributed in studied areas. The species of Sanionia have weakly compact soft tufts which are more often collected by gulls as material for nests both in Antarctic and Arctic regions (Parnikoza et al. 2015). Lichens in the nests were represented mainly by Usnea antarctica and $U$. aurantiacoatra (Jacq.) Bory on the Fildes Peninsula and Ardley Island and mostly $U$. antarctica on the Argentine Islands. In both localities, these lichens are part of a widely distributed fruticose lichen and moss cushion sub-formation on the South Shetlands and Argentine Islands (Lindsay 1971; Smith and Corner 1973). Tardigrades found in the present study probably represent typical species associated with the moss and lichen communities mentioned above and are not exclusively found in nests; however, this statement needs verification by further studies focused both on tardigrade fauna in nests and in surrounding vegetation. The specific soils of Antarctica, which contain a lot of primary remnants of bryophytes and lichens (Parnikoza et al. 2010) can be also a suitable habitat for tardigrades.

Tardigrades transported together with bryophytes and lichens by birds can just die in the nests or colonize a new area if the plants develop into suitable habitats or spread in soil substrata. It is also possible that tardigrades can be additionally supported by another aspect of bird activity. In the Arctic, seabirds (especially large colonies of the little auk, Alle alle Linnaeus, 1758) deposit large amounts of guano, which provides a lot of nutrients for poor tundra ecosystems and considerably affects local biogeochemistry and increases vegetation (Stempniewicz et al. 2007). A similar effect on vegetation is provided by the flying bird activity on Argentine Islands, which supports especially hair grass D. antartica stands, as part of a Sanionia community (Parnikoza et al. 2014). Zmudczyńska et al. (2012) showed that such nutrients have a positive effect on soil collembolan communities on Spitsbergen. Zawierucha et al. (2015a, b) showed that nutrients from little auk colonies positively affect not only tardigrade diversity and abundance, but also their size. However, Porazińska et al. (2002) reported the opposite results in penguin rookeries on Ross Island (Antarctic) and stated that excessive accumulations of nutrients increase soil salinity and limit the number of soil invertebrates such as nematodes, rotifers, and tardigrades. Similar results were obtained from Edmonson Point (Northern Victoria Land, Antarctica) by Smykla et al. (2010, 2012), who showed that tardigrades and rotifers were absent in soils from penguin colonies and the number of nematodes was significantly smaller in comparison to soils from other areas. Obviously the effects of bird nests and colonies on meiofauna are still poorly understood. However, the amount of organic input also seems to be dependent on the bird species (flying seabirds or penguins) and the size of the colony. In our study, tardigrades in nests were rather common, found in seven out of twelve nest samples studied. In total, 13 taxa were 
identified (12 to the species level), including four species new to science. Therefore, water bears are quite frequent, and rather diverse on studied area. However, our data also show that the tardigrade fauna in the studied area is still very poorly known. Our results are consistent with other studies conducted on the Antarctic Peninsula and neighbouring islands. In contrast, the invertebrate fauna is rather scanty in other regions, especially continental Antarctica (for review see Convey and McInnes 2005 and VelascoCastrillón et al. 2014).

Bryodelphax olszanowskii sp. nov. belongs to the weglarskae group of species (Kristensen et al. 2010), which are known from mosses and lichens around the world, but still rather rare. They have been found in mountains, polar regions and small islands like Sardinia or Rapa Nui (Pilato 1972; 1974; Bertolani et al. 1996; Kristensen et al. 2010; Kaczmarek et al. 2012; Gạsiorek et al. 2017). Two new Diphascon species belong to the homogeneous group of species that can be differentiated from other members of the group based mainly on morphometrical characters (Fontoura and Pilato 2007). The most common species from this group D. pingue pingue (Marcus, 1936) was considered, in the past, to be cosmopolitan (McInnes 1994), but based on the revision most of those reports should be confirmed (Pilato and Binda 1997/1998). Currently their distribution is probably restricted to the Palaearctic or Holarctic. The other species in this group are mainly known from their type localities or their distribution ranges are rather narrow (e.g. Pilato and Binda 1997/1998; 1999; Kaczmarek and Michalczyk 2004; and Fontoura and Pilato 2007). Five of them (including two described in this paper) are known from the Antarctica region (Pilato and Binda 1999). The last new species $H$. conwentzii sp. nov. belongs to dujardini-convergens complex (Kaczmarek and Michalczyk 2009), which is very problematic because of the lack of exact diagnoses of the nominal species, i.e. H. convergens (Urbanowicz, 1925) and $H$. dujardini. At present, a few species in this complex have been described from places around the world, and most of them are known only from their type localities (e.g. Miller et al. 2005; Tumanov 1997; Pilato et al. 2004, 2006, 2011, 2012b). The only widely distributed species are $H$. convergens, $H$. dujardini, H. microps Thulin, 1928 and $H$. pallidus Thulin, 1911 (McInnes 1994), however most of those reports (especially outside of the Palaearctic) are probably incorrect and need confirmation. The other species found in the present study (except E. m. merokensis) are typical Antarctic species reported from different parts of the continental and maritime Antarctic. The most common species in this study was $M$. aradasi, which was found in all positive samples what can be probably caused by relatively small area sampled. The discovery of E. m. merokensis in Antarctic is rather unusual. Although this species has been found in the Southern Hemisphere in Argentina and Chile, the type locality is in Norway, and most of its records are from the Northern Hemisphere. This may suggest either a cosmopolitan distribution of this species or the existence of cryptic taxa (morphologically identical or very similar), but such assumptions can be confirmed only by extensive molecular research. Since we found this species in the region where several research stations are located, it is also possible that E. m. merokensis was introduced to the Antarctic Peninsula region by humans.

Acknowledgements The authors thank the National Antarctic Scientific Centre of Ukraine for logistic support of our study. This study was carried out as part of the Ukrainian State target scientific and technical research programme in the Antarctic for 2011-2020. Studies also have been conducted within the framework of activities of BARg (Biodiversity and Astrobiology Research group).The authors also thank Professor R. Ochyra for consultations, M. Veselski for help in sample collections on the Argentine Islands, and Johannes Krietsch, Marie-Charlott Rümmler and Martin Senf for help in sample collections on the Fildes Peninsula. The authors also want to thank Cambridge Proofreading LLC (http://proofreading.org/) for help in improving the English in the manuscript.

Open Access This article is distributed under the terms of the Creative Commons Attribution 4.0 International License (http://crea tivecommons.org/licenses/by/4.0/), which permits unrestricted use, distribution, and reproduction in any medium, provided you give appropriate credit to the original author(s) and the source, provide a link to the Creative Commons license, and indicate if changes were made.

\section{References}

Beasley CW (1995) The phylum Tardigrada. Third Edition: (English Trans: Ramazzotti G, Maucci W). Published by the translator Clark Beasley, Abilene

Beasley CW, Kaczmarek Ł, Michalczyk Ł (2008) Doryphoribius mexicanus, a new species of Tardigrada (Eutardigrada: hypsibiidae) from Mexico (North America). Proc Biol Soc Wash 121:34-40. doi:10.2988/07-30.1

Bertolani R, Guidi A, Rebecchi L (1996) Tardigradi della Sardegna e di alcune piccole isole circum-sarde. Biogeographia 18:229-247

Bertolani R, Guidetti R, Marchioro T, Altiero T, Rebecchi L, Cesari M (2014) Phylogeny of Eutardigrada: new molecular data and their morphological support lead to the identification of new evolutionary lineages. Mol Phylogenet Evol 76:110-126. doi:10. 1016/j.ympev.2014.03.006

Binda MG, Pilato G (1992) Minibiotus furcatus, nuova posizione sistematica per Macrobiotus furcatus Ehrenberg, 1859, e descrizione di due nuove specie. Animalia 19:111-120

Binda MG, Pilato G, Lisi O (2005) Remarks on Macrobiotus furciger Murray, 1906 and description of three new species of the furciger group (Eutardigrada, Macrobiotidae). Zootaxa 1075:55-68

Convey P, McInnes SJ (2005) Exceptional tardigrade-dominated ecosystems in Ellsworth Land, Antarctica. Ecology 86(2):519-527. doi:10.1890/04-0684

Convey P, Bindschadler RA, di Prisco G, Fahrbach E, Gutt J, Hodgson DA, Mayewski P, Summerhayes CP, Turner J (2009) 
Antarctic climate change and the environment. Antarctic Sci 21:541-563. doi:10.1017/S0954102009990642

Dastych H (1984) The Tardigrada from Antarctica with description of several new species. Acta Zool Cracov 27:377-436

Dastych H (2002) Diphascon langhovdense (Sudzuki, 1964) stat. nov., a new taxonomic status for the semi-terrestrial tardigrade (Tardigrada). Acta Biol Benrodis 12:19-25

Degma P, Guidetti R (2007) Notes to the current checklist of Tardigrada. Zootaxa 1579:41-53

Degma P, Bertolani R, Guidetti R (2009-2017) Actual checklist of Tardigrada species. (Ver. 32: 01-06-2017) www.tardigrada. modena.unimo.it/miscellanea/Actual $\% 20$ checklist $\% 20$ of $\% 20 \mathrm{Tar}$ digrada.pdf

Doyère M (1840) Memoire sur les tardigrades. Ann Sci Nat Zool Paris Ser 2(14):269-362

Fontoura P, Morais P (2011) Assessment of traditional and geometric morphometrics for discriminating cryptic species of the Pseudechiniscus suillus complex (Tardigrada, Echiniscidae). J Zool Syst Evol Res 49(S1):26-33. doi:10.1111/j.1439-0469.2010. 00594.x

Fontoura P, Pilato G (2007) Diphascon (Diphascon) faialense sp. nov. a new species of Tardigrada (Eutardigrada, Hypsibiidae) from the Azores and a key to the species of the $D$. pingue group. Zootaxa 1589:47-55

Furmańczyk K, Ochyra R (1982) Plant communities of the Admiralty Bay region (King George Island) South Shetland Islands, Antarctic) I.Jasnorzewski Gardens. Pol Polar Res 3:25-39

Gąsiorek P, Stec D, Morek W, Marnissi J, Michalczyk $Ł$ (2017) The tardigrade fauna of Tunisia, with an integrative description of Bryodelphax maculatus sp. nov. (Heterotardigrada: Echiniscidae). Afr Zool 52:77-89. doi:10.1080/15627020.2017.1297688

Guidetti R, Bertolani R (2005) Tardigrade taxonomy: an updated check list of the taxa and a list of characters for their identification. Zootaxa 845:1-46

Guidetti R, Rebecchi L, Cesari M, McInnes SJ (2014) Mopsechiniscus franciscae, a new species of a rare genus of Tardigrada from continental Antarctica. Polar Biol 37:1221-1233. doi:10.1007/ s00300-014-1514-x

Kaczmarek $Ł$, Michalczyk $Ł$ (2004) Notes on some tardigrades from South Africa, with the description of Diphascon (Diphascon) zaniewi sp. nov. (Eutardigrada: Hypsibiidae). Zootaxa 576:1-6. doi:10.11646/zootaxa.576.1.1

Kaczmarek Ł, Michalczyk $Ł$ (2009) Redescription of Hypsibius microps Thulin, 1928 and H. pallidus Thulin, 1911 (Eutardigrada: Hypsibiidae) based on the type material from the Thulin collection. Zootaxa 2275:60-68

Kaczmarek Ł, Zawierucha K, Smykla J, Michalczyk Ł (2012) Tardigrada of the Revdelen (Spitsbergen) with the descriptions of two new species: Bryodelphax parvuspolaris (Heterotardigrada) and Isohypsibius coulsoni (Eutardigrada). Polar Biol 35:1013-1026. doi:10.1007/s00300-011-1149-0

Kaczmarek Ł, Janko K, Smykla J, Michalczyk Ł (2014a) Soil tardigrades from the Antarctic Peninsula with a description of a new species and some remarks on the genus Ramajendas (Eutardigrada, Isohypsibiidae). Polar Rec 50:176-182. doi:10. 1017/S0032247413000168

Kaczmarek Ł, Cytan J, Zawierucha K, Diduszko D, Michalczyk Ł (2014b) Tardigrades from Peru (South America), with descriptions of three new species of Parachela. Zootaxa 3790:357-379. doi:10.11646/zootaxa.3790.2.5

Kaczmarek Ł, Michalczyk Ł, McInnes SJ (2015) Annotated zoogeography of non-marine Tardigrada. Part II: South America. Zootaxa 3923:1-107. doi:10.11646/zootaxa.3923.1.1

Kimble JM (2004) Cryosols. Permafrost-affected soils. Springer, Berlin
Kristensen JM (1987) Generic revision of the Echiniscidae (Heterotardigrada), with a discussion of the origin of the family. In: Bartolani R (ed) Biology of Tardigrada, selected symposia and monographs. Mucci Modena, Modena, pp 261-335

Kristensen RM, Michalczyk $Ł$, Kaczmarek $Ł$ (2010) The first record of the genus Bryodelphax (Tardigrada: Heterotardigrada: Echiniscidae) from Easter Island, Rapa Nui (Pacific Ocean, Chile) with the description of a new species, Bryodelphax aaseae. Zootaxa 2343:45-56

Lindsay DC (1971) Vegetation of the South Shetland Islands. Br Antarct Surv Bull 25:59-83

Maucci W (1988) Tardigrada from Patagonia (Southern South America) with description of three new species. Rev Chil Entomol 16:5-13

McInnes SJ (1994) Zoogeographic distribution of terrestrial/freshwater tardigrades from current literature. J Nat Hist 28:257-352. doi:10.1080/00222939400770131

McInnes SJ (2010) Echiniscus corrugicaudatus (Heterotardigrada; Echiniscidae) a new species from Ellsworth Land, Antarctica. Polar Biol 33:59-70. doi:10.1007/s00300-009-0684-4

Michalczyk Ł, Kaczmarek $Ł$ (2006) Revision of the Echiniscus bigranulatus group with a description of a new species Echiniscus madonnae (Tardigrada: Heterotardigrada: Echiniscidae) from South America. Zootaxa 1154:1-26

Michalczyk Ł, Kaczmarek $Ł$ (2007) Echiniscus ganczareki, a new species of Tardigrada (Heterotardigrada: Echiniscus bigranulatus group) from Costa Rica. Zootaxa 1471:15-25

Michalczyk Ł, Kaczmarek Ł (2013) The Tardigrada Register: a comprehensive online data repository for tardigrade taxonomy. J Limnol 72(S1):175-181. doi:10.4081/jlimnol.2013.s1.e22

Miller WR, McInnes SJ, Bergstrøm DM (2005) Tardigrades of the Australian Antarctic: Hypsibius heardensis (Eutardigrada: Hypsibiidae: dujardini group) a new species from sub-Antarctic Heard Island. Zootaxa 1022:57-64

Nelson DR, Guidetti R, Rebecchi L (2015) Phylum Tardigrada. In: Thorp JH, Covich AP (eds) Freshwater invertebrates: ecology and general biology, Vol. 1, 4th edn. pp 347-380

Parnikoza I, Kozeretska O, Kozeretska I (2009) Is a translocation of indigenous plant material successful in the Maritime Antarctic? Polarforschung 78:25-27

Parnikoza I, Korsun S, Kozeretska I, Kunakh V (2010) Discussion note on soil development under the influence of terrestrial vegetation at two distant regions of the maritime Antarctic. Polarforschung 80:181-185

Parnikoza I, Dykyy I, Ivanets V, Kozeretska I, Kunakh V, Rozhok A, Ochyra R, Convey P (2012) Use of Deschampsia antarctica for nest building by the kelp gull in the Argentine Island area (maritime Antarctica) and its possible role in plant dispersal. Polar Biol 11:1753-1758. doi:10.1007/s00300-012-1212-5

Parnikoza IY, Abakumov EV, Dykyy IV, Pilipenko DV, Shvydun PP, Kozeretska IA, Kunakh VA (2014) Influence of birds on the spatial distribution of Deschampsia antarctica (Desv.) on Galindez Island (Argentine Islands, maritime Antarctic). Russ Ornithol J 23:3095-3107

Parnikoza I, Hadwiczak M, Barcikowski M, Stempniewicz L (2015) Arctic and Antarctic large white-headed gull species nest materials-similarity across the globe. 26th International Congress on Polar Research: High latitudes and high mountains: driver of or driven by global change? German Society for Polar Research, Munich, pp 117-118

Pilato G (1972) Prime osservazioni sui Tardigradi delle Isole Egadi. Boll Sed Acc Gioenia Sc Nat Catania, Ser IV 5:111-124

Pilato G (1974) Studio su Diphascon scoticum J. Murr., 1905 (Eutardigrada) e alcune altre specie ritenute ad esso affini. Animalia 1:73-88 
Pilato G (1981) Analisi di nuovi caratteri nello studio degli Eutardigradi. Animalia 8:51-57

Pilato G, Binda MG (1997a) Acutuncus, a new genus of Hypsibiidae (Eutardigrada). Entomol Mitt Zool Mus Hambg 12:159-162

Pilato G, Binda MG (1997/1998) A comparison of Diphascon (D.) alpinum Murray, 1906, D. (D.) chilenense Plate, 1889 and D. (D.) pingue Marcus, 1936 (Tardigrada), and description of a new species. Zool Anz 236:181-185

Pilato G, Binda MG (1999) Three new species of Diphascon of the pingue group (Eutardigrada, Hypsibiidae) from Antarctica. Polar Biol 21:335-342. doi:10.1007/s003000050370

Pilato G, Binda MG (2010) Definition of families, subfamilies, genera and subgenera of the Eutardigrada, and keys to their identification. Zootaxa 2404:1-52

Pilato G, Binda MG, Napolitano A, Moncada E (2004) Remarks on some species of tardigrades from South America with description of two new species. J Nat Hist 38:1081-1086. doi:10.1080/ 0022293031000071541

Pilato G, Binda MG, Lisi O (2006) Three new species of eutardigrades from Seychelles. N Z J Zool 33:39-48. doi:10.1080/ 03014223.2006.9518429

Pilato G, Kiosya Y, Lisi O, Inshina V, Biserov V (2011) Annotated list of Tardigrada records from Ukraine with the description of three new species. Zootaxa 3123:1-31

Pilato G, McInnes SJ, Lisi O (2012a) Hebesuncus mollispinus (Eutardigrada, Hypsibiidae), a new species from maritime Antarctica. Zootaxa 3446:60-68

Pilato G, Kiosya Y, Lisi O, Sabella G (2012b) New records of Eutardigrada from Belarus with the description of three new species. Zootaxa 3179:39-60

Porazińska DL, Wall DH, Virginia RA (2002) Invertebrates in ornithogenic soils on Ross Island, Antarctica. Polar Biol 25:569-574. doi:10.1007/s00300-002-0386-7

Pugh PJA, Convey P (2008) Surviving out in the cold: Antarctic endemic invertebrates and their refugia. $\mathrm{J}$ Biogeogr 35:2176-2186. doi:10.1111/j.1365-2699.2008.01953.x

Ramazzotti G, Maucci W (1983) Il Phylum Tardigrada. Mem dell'Ist Ital Idrobiol. Pallanza 41:1-1012

Riffenburh B (2007) Encyclopedia of the Antarctic. Taylor Francis Group, New York

Rossi G, Claps M, Ardohain D (2009) Tardigrades from northwestern Patagonia (Nauquen Province, Argentina) with the description of three new species. Zootaxa 2095:21-36

Roszkowska M, Stec D, Ciobanu DA, Kaczmarek Ł (2016) Tardigrades from Nahuel Huapi National Park (Argentina, South America) with descriptions of two new Macrobiotidae species. Zootaxa 4105:243-260. doi:10.11646/zootaxa.4105.3.2

Smith RIL, Corner RWM (1973) Vegetation of the Arthur HarbourArgentine Islands region of the Antarctic Peninsula. Br Antarct Surv Bull 33(34):89-122

Smykla J, Porazińska DL, Iakovenko N, Janko K, Weiner WM, Niedbała W, Drewnik M (2010) Studies on the Antarctic soil invertebrates: preliminary data on rotifers (Rotatoria) with notes on other taxa from Edmonson Point (northern Victoria Land, continental Antarctic). Acta Soc Zool Bohem 74:135-140

Smykla J, Iakovenko N, Devetter M, Kaczmarek Ł (2012) Diversity and distribution of tardigrades in soils of Edmonson Point (Northern Victoria Land, continental Antarctica). Czech Polar Rep 2:61-70. doi:10.5817/CPR2012-2-6

Stec D, Smolak R, Kaczmarek Ł, Michalczyk Ł (2015) An integrative description of Macrobiotus paulinae sp. nov. (Tardigrada: Eutardigrada: Macrobiotidae: hufelandi group) from Kenya. Zootaxa 4052:501-526. doi:10.11646/zootaxa.4052.5.1

Stempniewicz L, Błachowiak-Samołyk K, Wesławski JM (2007) Impact of climate change on zooplankton communities, seabird populations and Arctic terrestrial ecosystem-a scenario. Deep Sea Res Part II 54:2934-2945. doi:10.1016/j.dsr2.2007.08.012

Tsujimoto M, McInnes SJ, Convey P, Imura S (2014) Preliminary description of tardigrade species diversity and distribution pattern around coastal Syowa Station and inland Sør Rondane Mountains, Dronning Maud Land,East Antarctica. Polar Biol 37(9):1361-1367. doi:10.1007/s00300-014-1516-8

Tumanov DV (1997) Hypsibius iskandarovi sp.n a new species of Tardigrada from fresh waters of North-West Russia (Tardigrada: Hypsibiidae). Zoosyst Rossica 5:219-220

Turner J, Colwell SR, Marshall GJ, Lachlan-Cope TA, Carleton AM, Jones PD, Lagun V, Reid PA, Iagovkina S (2005) Antarctic climate change during the last 50 years. Int $\mathbf{J}$ Climatol 25:279-294. doi:10.1002/joc.1130

Vecchi M, Cesari M, Bertolani R, Jönsson KI, Rebecchi L, Guidetti R (2016) Integrative systematic studies on tardigrades from Antarctica identify new genera and new species within Macrobiotoidea and Echiniscoidea. Invertebr Syst 30:303-322

Velasco-Castrillón A, Gibson JAE, Stevens MI (2014) A review of current Antarctic limno-terrestrial microfauna. Polar Biol 37(10):1517-1531. doi:10.1007/s00300-014-1544-4

Vicente F, Bertolani R (2013) Considerations on the taxonomy of the Phylum Tardigrada. Zootaxa 3626:245-248. doi:10.11646/zoo taxa.3626.2.2

Zawierucha K, Smykla J, Michalczyk Ł, Gołdyn B, Kaczmarek Ł (2015a) Distribution and diversity of Tardigrada along altitudinal gradients in the Hornsund, West Spitsbergen (Arctic). Polar Res 34:24168. doi:10.3402/polar.v34.24168

Zawierucha K, Cytan J, Smykla J, Wojczulanis-Jakubas K, Kaczmarek Ł, Kosicki JZ, Michalczyk Ł (2015b) Sea bird guano boosts body size of water bears (Tardigrada) inhabiting the Arctic tundra. Polar Biol 38(4):579-582. doi:10.1007/s00300014-1591-x

Zmudczyńska K, Olejniczak I, Zwolicki A, Iliszko L, Convey P, Stempniewicz L (2012) Influence of allochthonous nutrients delivered by colonial seabirds on soil collembolan communities on Spitsbergen. Polar Biol 35:12331245. doi:10.1007/s00300012-1169-4 